\title{
Theoretical Framework to Assess Green Roof Performance in Mitigating Urban Flooding as a Potential Nature-Based Solution
}

\author{
Arunima Sarkar Basu ${ }^{1}$, Francesco Pilla ${ }^{1, *}{ }^{\mathbb{D}}$, Srikanta Sannigrahi ${ }^{1}\left(\mathbb{D}\right.$, Rémi Gengembre $^{2}$, Antoine Guilland ${ }^{2}$ \\ and Bidroha Basu ${ }^{3}$ (D) \\ 1 School of Architecture, Planning and Environmental Policy, University College Dublin, \\ D04 V1W8 Dublin 4, Ireland; arunima.sarkar@ucdconnect.ie (A.S.B.); srikanta.sannigrahi@ucd.ie (S.S.) \\ 2 École Centrale de Marseille, 13013 Marseille, France; remi.gengembre@centrale-marseille.fr (R.G.); \\ antoine.guilland@centrale-marseille.fr (A.G.) \\ 3 Civil Structural and Environmental Engineering, Munster Technological University, T12 P928 Cork, Ireland; \\ bidroha.basu@mtu.ie \\ * Correspondence: francesco.pilla@ucd.ie; Tel.: +353-1-716-2733
}

Citation: Basu, A.S.; Pilla, F.; Sannigrahi, S.; Gengembre, R.; Guilland, A.; Basu, B. Theoretical Framework to Assess Green Roof Performance in Mitigating Urban Flooding as a Potential Nature-Based Solution. Sustainability 2021, 13, 13231. https://doi.org/10.3390/su132313231

Academic Editor: Andrzej Walega

Received: 7 October 2021

Accepted: 25 November 2021

Published: 29 November 2021

Publisher's Note: MDPI stays neutral with regard to jurisdictional claims in published maps and institutional affiliations.

Copyright: (c) 2021 by the authors. Licensee MDPI, Basel, Switzerland. This article is an open access article distributed under the terms and conditions of the Creative Commons Attribution (CC BY) license (https:// creativecommons.org/licenses/by/ $4.0 /)$.

\begin{abstract}
Increases in extreme hydro-meteorological events due to climate change and decreases in soil permeability and infiltration due to urbanization have increased the risk of flooding, particularly in cities. The limitation of the expansion of conventional drainage systems to manage excess stormwater leads to the application of nature-based solutions (NBS) to control flooding. This study explores potential of green roof NBS for rainfall-fed flood reduction, which can utilize existing roof space for deployment. A detailed literature survey using systematic literature-search procedures was conducted to investigate the performance of extensive/intensive green roofs in runoff reduction using monitoring/modeling approaches. Since limited studies have explored the use of semi-intensive green roofs for flood management, a new simulation study has been developed to compare the effectiveness of semi-intensive green roofs. The performance of different types of vegetation used on green roofs in runoff reduction was investigated using a simulation study, which was validated using a real-world green roof deployed in Dublin.
\end{abstract}

Keywords: nature-based solutions; green roofs; flood control; evapotranspiration; soil moisture content

\section{Introduction}

The rapid growth of the global population has resulted in the acceleration of urbanized areas due to the construction of buildings, bridges, and roads [1]. About half of the human population worldwide lives in urban areas [2]. The negative consequence of urbanized growth is an increase in impervious surfaces, which has replaced natural land covers and grasslands [3,4].

Moreover, the loss of natural land covers led to the degradation of urban green spaces [5]. This resulted in a reduction in soil capacity, and reduced soil permeability, infiltration, and the storage of rainwater in soil [6-8]. The gradual loss in the permeability of soil has increased the rate of runoff, leading to a high risk of urban flooding $[9,10]$. As a result of the growth of impervious surfaces, the flood-proneness in cities has shown a rising trend [11,12]. Increases in flood proneness have led to the alteration of hydrological fluxes of a drainage area $[13,14]$. Further, the process of the disturbance of hydrological fluxes has also been attributed as an impact of climate change and global warming, caused by anthropogenic factors $[15,16]$. A trend in a significant rise in precipitation has been observed as a result of a warming world. The increase in heavy precipitation aggravates the flooding process further [17]. This is attributed to the fact that the increase in precipitation leads to an increase in streamflow [18]. These factors collectively demonstrate the risk of flooding in various megacities [19]. 
Various studies have reported that the impact of extreme precipitation is considerably higher on conventional forms of drainage systems, i.e., sewage, pumping station drainage systems, etc. $[20,21]$ The rapid growth of the population has further increased the burden on the conventional drainage system in terms of managing the increased volume of runoff and wastewater [22]. To overcome the severity of urban flooding, the European Commission enacted the nature-based solution (NBS) framework as a part of the Horizon 2020 programme for research and innovation [23].

Nature-based solutions have demonstrated a high potential of environmental welfare through a clear vision of natural resource management by capitalizing on the innovation and optimal use of ecosystem services [24-26]. Therefore, to evaluate the positive impacts of the NBS, this paper briefly talks about the characteristic of floods in the next section, and thereafter, talks about the various provisions supporting the NBS, its various types, and its effectiveness in managing floods in greater detail. The objective of this paper was to investigate the effectiveness of different types of green roofs through a literature survey and modeling studies. Furthermore, since the performance evaluation of semi-intensive green roofs is limited in the literature, a new simulation model was developed to compare the effectiveness of extensive and semi-intensive green roofs in the reduction of rainfall-fed runoff.

\subsection{Characterisation of Flood Events}

Several studies have been conducted to inspect the nature of hydrological risks related to urban floods [27-29]. The European Environmental Agency investigated the flood risk by examining historical data from 1980 to 2010 and reported that there has been a significant rise in flooding. The study claimed that the situation will get worse in the future [30]. Guerreiro et al. [31] predicted that more than a hundred cities in Europe will be vulnerable to two or more climate impacts, leading to an increase in flooding. In another study, Marchi et al. [28] adopted high-resolution data-based approaches to understanding the hydrometeorological determinants of floods, and analyzed 25 extreme flood events across Europe. This study observed that runoff response exhibited short lag times (mostly $<6 \mathrm{~h}$ ) throughout the study period during the flooding. Another study, conducted by de Moel et al. [29], highlighted the various approaches, models, tools, and programs available for producing spatially explicit flood maps for Europe. This study observed that, among the different components of a flood map, the flood extent maps were the most frequently used flood maps taken into consideration by $80 \%$ of the study. Apart from the flood extent, eight countries have considered flood depth, two countries (Switzerland and Luxembourg) have considered velocity, while, very rarely, propagation (Hungary and Netherlands) was considered for generating the data-driven flood maps.

As a result of various flood risk assessment studies, national flood management (NFM) is a major focus amongst various government-funded research projects and investments [32]. NFM encourages water conservation through practices such as stream conservation and habitat management, with the aim to 'slow the flow'. This means that the aim is to reduce the peak flow by the deployment of techniques to hold the surge of water received from heavy precipitation [33].

To mitigate the substantial harm caused by flooding, it is imperative to focus on the techniques to reduce the peak flow of water. In order to combat the challenges of flooding, nature-based solutions have been explored as a potential urban flood-control mechanism.

\subsection{Nature-Based Solutions: An Alternate Approach to Address Environmental and Socio-Ecological Problems}

Nature-based solutions can potentially regulate the imbalances in water caused mainly by climate change [34]. NBS can be termed as the bundle of natural and ecological functions that are proven to be beneficial to address varied socio-ecological challenges in cities [35]. This means that the implementation of NBS in the form of parks, street trees, or other forms of urban green areas helps with the provisioning of habitat space responsible for the regulation of flood events [36]. 
The European Commission (EC) has defined nature-based solutions as viable alternatives to address the socio-ecological challenges with 'solutions that are inspired and supported by nature, which are cost-effective, simultaneously provide environmental, social and economic benefits and help build resilience. Such solutions bring more and more diverse, nature, and natural features and processes into cities, landscapes, and seascapes, through locally adapted, resourceefficient, and systemic interventions' [37]. The Sendai Framework for Disaster Risk Reduction (2015-2030) emphasizes disaster risk management by the sustainable management of the environment and of ecosystems [38].

The Paris Agreement on climate change focused on the utilization of natural ecosystems for climate benefits [39]. The nature conservancy, UNDP, mentions that protected areas can help mitigate and adapt to climate change by maintaining ecosystem integrity, buffering local climates, and reducing the risk and impact of extreme events [40]. The sustainable development goals (SDG) 11 and 13 focus on making cities and human settlements safe by adapting strategies to mitigate the effects of climate change [35]. It is well-established in the literature that the use of NBS would lead to the growth of soft engineering approaches for nourishing synergies between natural capitals, an economically empowered population, and the improvement of health due to a reduced disaster risk, such as floods [41-43]. NBS as an alternative to grey infrastructure, such as concrete walls, can be developed by increasing green areas through urban forestry and plantation [44], preserving urban inland water bodies and wetlands $[45,46]$, the deployment of sustainable, cost-efficient, and environment-friendly urban drainage and sewage systems [47], and reducing the impervious surface cover by increasing green cover [48]. However, substantial evidence is required to understand the importance of NBS as alternatives to hard-engineered solutions, and their positive implications must bring out collective economic, social, and environmental benefits in producing various regulatory, provisioning, supporting, and cultural urban ecosystem services.

NBS have proven to be effective in addressing many societal challenges, including upgrading human welfare and status of livelihood, the regeneration of urban ecosystems, the improvement of coastal resilience to natural disasters, sustainable watershed management through ecosystem-based adaptations, the increasing of resource efficiency, the promoting of sustainable uses of natural resources, the formulation of valuation markets for intangible ecosystem functions and services, and the increasing of carbon sequestration through cost-effective green infrastructure planning $[35,49,50]$.

\subsection{Characteristics and Types of NBS}

The terminology of NBS was introduced in 2008 to combat the rising impact of climate change by improving environmental performance through (i) the mitigation of the impact of hydro-meteorological hazard risks such as floods, (ii) the improvement of ecosystem services, and (iii) the improvement of overall human health and wellbeing. The performance of nature-based solutions for flood mitigation could potentially be evaluated based on the extent to which the reduction in the rate of runoff volume of peak flow, and the increase in time until the peak, has been achieved. Moreover, an increase in evapotranspiration, soil moisture retention, and crop yield, an improvement in water quality (through abatement of pollutants), and a reduction in urban heat island effects can also be analyzed when evaluating the performance of NBS [51-53].

Some of the proposed varieties of NBS that are in use for flood control are bioswales, rainwater harvesting, tree pits, attenuation tanks, infiltration trenches, and green roofs [54]. Applications of those NBS are mostly observed in megacities; however, wetlands are also found in urban areas, while buffer strips of agriculture, wetlands, and riparian forests are deployed in large river catchments as nature-based solutions to flooding [55].

Green roofs help with better stormwater management by increasing the rate of infiltration and evapotranspiration, thereby reducing the overall rainfall-fed runoff flow from the roof to the ground [56]. This study investigates various aspects of green roofs as the chosen NBS. A major advantage of green roofs is that they can utilize an already-existing 
free space (roofs) for deployment, whereas all the other NBS would require considerable space for deployment that might not be available in an already-developed urban area or in megacities [57]. Hence, this study extensively analyzes the prospective performance of green roofs as NBS for mitigating floods.

\section{Methodology Used to Investigate the Effectiveness of Green Roofs Based on Literature}

This paper aims to understand the potential performance of green roofs. To achieve this, an extensive literature review was conducted about green roofs to investigate their nature and types, and their performance as NBS in the reduction of rainfall-fed runoff using monitoring and modeling approaches through a systematic literature search. Furthermore, this study also developed a new simulation model to compare the effectiveness of extensive and semi-intensive green roofs in the reduction of rainfall-fed runoff. It needs to be noted that the performance evaluation of semi-intensive green roofs is limited in the literature.

\subsection{Systematic Literature Review}

Literature searches and reviews based on the Preferred Reporting Items for Systematic Reviews and Meta-Analysis (PRISMA) [58,59] was used for conducting the literature searches. The objective of the systematic literature review was to synthesize and understand factors that resulted in the existence of green roofs as a nature-based solution, how the performance of green roofs as a nature-based solution has helped in the management of run-off and retention processes, and what gaps and research need to be addressed. The goal of the literature review was to answer the following questions: (i) How do the deployed green roofs help in the management of run-off control corresponding to various spatio-temporal conditions (various geographical conditions and scales)? (ii) What type of vegetation, substrate and green roof size has performed well when the green roof was deployed? (iii) What type of green roof innovation and development has been made over the last few years? (iv) What parameters have been successful in understanding the performance criteria of the deployed green roof? Finally, (v) which assessment approaches and models were used previously to understand the performance of deployed green roofs corresponding to different weather and climatic conditions?

Peer-reviewed research articles were identified from the Web of Science, Scopus, ScienceDirect, and Google Scholar databases, covering the period from January 2005 to April 2020 and based on a set of pre-defined search keywords focusing on the performance of green roofs. The keywords used were Floods, Nature-Based Solutions (NBS), Green Roofs, Stormwater Runoff, river flow. The search results were further refined based on the available literature where the full text was available. Diverse sources of literature from a multi-disciplinary background were returned because of the search. More than 3000 articles initially appeared because of the search. However, the search was further refined by selecting the articles that have undergone the peer-review process. The articles containing floods as a hazard were included in the literature search; the rest of the hazards were excluded from processing in this article. To further refine the initial set of articles, a detailed search was conducted on NBS types and their effectiveness, green roof type, performance, and benefits, using the following keywords: floods, green roof performance, reduction in runoff. The final search from the pieces of literature that were considered for this systematic review included 232 papers. The articles which were considered dealt mostly with understanding the reasons for the intensification of floods. The other consequences were associated with flooding and urbanization, the flood control mechanism, and the effectiveness of NBS as flood control. The various policy implications focus on NBS, the types of NBS, green roofs as a type of NBS, the various types of green roofs, and the policies deployed for upscaling the green roof systems. 


\subsection{Performance Evaluation Study}

Based on the literature search, around 136 papers (out of 232) were identified that discussed the effectiveness of green roofs. The set excluded conference proceedings and non-peer-reviewed articles. After removing repeatedness and similarities from the selected 136 articles, 47 papers were extensively reviewed, and the outcome from those papers was documented in this study. Furthermore, a new simulation study has been proposed to investigate the effectiveness of extensive and semi-intensive green roofs in the reduction of rainfall-fed runoff by considering a different variety of vegetation that can replace the conventional vegetation used for green roofs. The types of vegetation range from fruit, medicinal plants, and cash crops. The following section discusses the different aspects of green roofs in detail, while Section 4 provides details on the performance evaluation of green roofs in runoff reduction noted in the literature survey and based on the proposed simulation study.

\section{Evolutions, Technical Details, and Co-Benefits of Green Roofs}

\subsection{Evolutions of Green Roofs}

Green roofs were anciently popular as rooftop gardens. The most popular of them were the hanging gardens of Babylon, established around 500BCE. In the recent past, many countries, such as Sweden, Finland, Iceland, Denmark, and Norway, started covering their roofs with sod during extreme climatic conditions. The modern green roof system was formalized in Germany in the year 1960. In Germany, the construction of green roofs was initially started for the reduction of energy consumption in the buildings. Initially, in Germany, around ten percent of the buildings across several cities had green roofs deployed on them [60]. The modern green roofs were mainly used for improving urban biodiversity, ecological enrichment, and the design of cost-effective rooftops. With technological advancements, the performances of green roofs were tested by implementing different vegetation substrates for achieving an optimal level of runoff retention [61]. Herman [62] reported that green-roof deployment has been responsible for managing various socio-ecological challenges over the past twenty years. These applications have become significantly popular in Germany, Austria, and Switzerland. In 2003, nearly $14 \%\left(13.5 \mathrm{~km}^{2}\right)$ of the total area covering rooftops in Germany was supported by green roofs. FLL [63] proposed an updated design for modern green-roof construction. Subsequently, new legislation was passed favoring the construction of green roofs on newly built or renovated buildings with flat roofs in Switzerland [60,64]. In the UK, the Construction Industry Research and Information Association's Sustainable Urban Drainage System (CIRIA SUDS) guidance [65] has strongly recommended the application of green roofs as an effective and sustainable urban drainage system. CIRIA had designed and formulated guidelines providing a theoretical and technical framework for installing green roofs and living walls in the UK [65]. In Toronto, the Green Roof Bylaw and the Eco-Roof Incentive program was enacted, which led to a substantial increases in green roof grants, subject to the approval of the city council. The Green Roof Bylaw required the construction of green roofs on new industrial, commercial, as well as residential infrastructure. Eco-incentive programmes aided new Catholic and public schools to deploy green roofs 'voluntarily' on buildings with areas less than 2000 square meters. The New York City Building Code has defined that new and existing buildings undergoing renovations will require $100 \%$ available roof space as a sustainable roofing zone. The sustainable roofing zone covers green roofing, solar panels, and wind turbines in its definition. Similarly, a Stormwater Retention Credit Training Program has been implemented in Washington DC, where every gallon of stormwater retained through a deployed green roof earns one credit. The credits are sold to the Department of Environment at a price ranging from USD 1.70 to USD $1.95[57,66]$.

The European Commission [67] published the strategic framework as a part of the natural capital accounting report to support the deployment of green and blue roofs as an infrastructural mechanism through natural solutions. The aim of the framework is to improve the flow of ecosystems by increasing urban green spaces. The EC has drawn 
attention to the deployment of zero-energy buildings within the EU from the year 2020. This EU initiative to deploy the renovation strategy is designed to help European countries to comply with the Paris Agreement on climate change. The report has a special mention of nature-based solutions, such as green roofs and other green infrastructure [68].

The Greater Dublin Drainage Study of 2005 [69] has recommended green roofs as a sustainable urban drainage system for managing run-off and stormwater. Moreover, green roofs have also received significant importance in improving water quality and habitat management. The green rooftops have received a special mention in the Dublin city council's green infrastructure strategy 2016-2022 for water management [70].

\subsection{Technical Description of Green Roofs}

The composition of a green roof usually consists of five components [71-74]: (i) a vegetation platform as the topmost layer, followed by (ii) a planting substrate medium (soil), (iii) a geotextile filter, (iv) a drainage layer placed as the bottom-most part of the green roof portion, and (v) a waterproof membrane bonded to the other layers and which acts as a protective barrier for the real roof (Figure 1). The waterproof layer helps with the easy repair of the green roof in case of leakage from the other substrates of the green roof. The drainage and retention layers drain the water percolates through soil as runoff. The geotextile filter functions as a protective layer to prevent other parts from falling into the drainage layer and blocking the drainage system. The planting medium, combined with the vegetation layer, reduces the runoff through evapotranspiration and water-storage activities. The characteristics and structure of a green roof implementation have a direct influence on its performance and efficiency. Despite having varying degrees of performance, the basic structure of a green roof remains unchanged (as described in Figure 1).
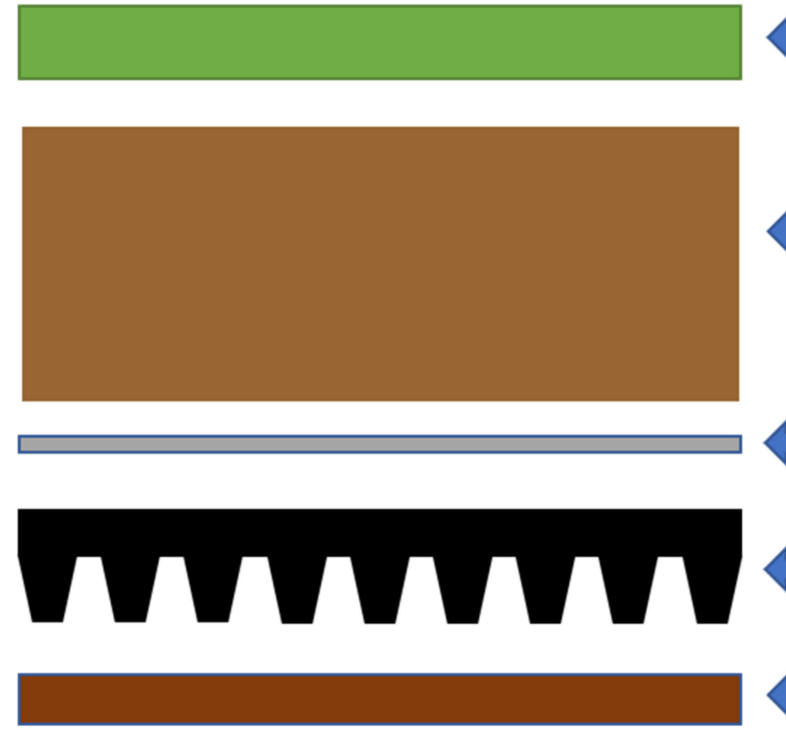

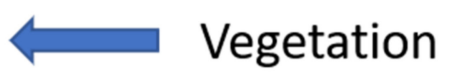

\section{Planting substrate medium}

\section{Geotextile filter}

\section{Drainage layer}

\section{Waterproof membrane}

Figure 1. Typical structure of a green roof.

The substrate (planting medium) used for growing the vegetation in a green roof can have a variable level of depths. Based on the depth of each layer used in the green roof system, the system can be classified as extensive, intensive, or semi-intensive. The major advantage of extensive green roofs is that they are lightweight, require low maintenance of the rooftops, require less nutrition for the plants, and do not need any irrigation. On the other hand, the intensive green roofs are considerably heavier, need specific building and rooftop designs for deployment, and require regular maintenance and irrigation. The semiintensive green roofs are a combination of both extensive as well as intensive green roofs. A wider variety of plants can be included in semi-intensive green roofs compared to the extensive roofs, have lighter weights compared to intensive roofs, and generally do not 
require any specific design of the building and rooftops; however, the maintenance and irrigation requirements depend on the type of plantation. The extensive green roofs have substrate depths ranging from 6 to $20 \mathrm{~cm}$ and can weigh approximately 20 to $150 \mathrm{~kg}$ per square meter. The plant species used for extensive green roofs are shallow-rooted plant varieties such as grass, sedum, moss, and other drought-resistant species [73]. Intensive green roofs are more favorable for deep-rooted plant species. The substrate depth of intensive green roofs can have a 15-cm deep substrate, which can support the growth of trees and shrubs. Intensive green roofs have shown a greater effectiveness in controlling surface runoffs, compared to the other variants of green roofs. The choice of plant variant for green roofs ranges from perennial plants to small trees. Intensive green roofs are heavier in weight, ranging from 180 to $500 \mathrm{~kg}$ per square meter. The deeper substrates of intensive green roofs have a synergic effect on enriching biodiversity and biomass produced by trees growing in the vegetation layer [75]. The semi-intensive green roofs can weigh between 120 and $200 \mathrm{~kg}$ per square meter. The intensive green roofs are the most expensive and the extensive green roofs are the least expensive to install and maintain.

The overall performance of the green roof system is evaluated by observing the following characteristics of the hydrological processes: (i) prolonging the runoff initiation; (ii) reduction of the volume of runoff; and (iii) extension of the runoff process via slow releases of excess substrate pore water [76]. The excess soil water and moisture contents will be merged with the downstream drainage system [77]. During a normal rainfall event, green roofs store the rainwater in the substrate/vegetation layer. The stored water subsequently evaporates from the substrate or vegetated soil surface $[78,79]$. Conversely, the extensive green roofs are less heavy, lightweight, cheaper, and require less maintenance costs and thus have gained wider acceptability $[71,73,74]$. The type of vegetation used for the construction of a green roof is widely dependent on various factors, such as the climatic conditions, the season of occurrence, and the type of irrigation used for cultivation [80]. Some studies suggested that intensive green roofs can sometimes add extra stress to the building structure. The trees and bushes used in intensive green roofs may have a deeper growing medium, which carries the extra weight associated with it [81]. Bengtsson et al. [82] suggest that the deployment of an intensive roof might require modifications to the building.

\subsection{Co-Benefits of Green Roofs}

It has been observed in various pieces of literature that green roofs have multiple co-benefits associated with their operation, along with their main benefit of increasing stormwater retention [83-86], attenuating the peak discharge volume $[77,87]$ and delaying the peak discharge $[88,89]$. The constructed green roofs can enrich biodiversity and ecological resources by helping the growth of plants and allowing the associated natural habitats to colonize $[90,91]$. The green roofs have been shown to have an increase in thermal comfort at the city scale [92-94]. Furthermore, the green roofs help with the beautification of landscapes, which has helped with the mental well-being of the population [95,96]. Apart from flood control, green roofs have also shown the reduction of air pollution [97-99]. As the major focus of this research is on flood control, a detailed study was conducted to investigate the effect of green roofs on flood mitigation alone.

\section{Evaluating Green Roofs Performances in Flood Mitigation/Control}

The potential of green roofs in controlling floods induced by rainfall-fed runoff can be evaluated mainly through one of the three factors: (i) decrease in total flood volume, (ii) decrease in peak flow, and (iii) increase in time taken to reach peak flow from the start of the rainfall event. A detailed literature survey was conducted to identify a list of research publications that estimated the effectiveness of green roofs used for the reduction of rainfallfed runoff. The analysis can be broadly classified into two subcategories, a monitoringbased approach and a modeling-based approach. In the monitoring approach, runoff data from an existing green roof was collected and compared with runoff data without 
green roofs, whereas, for the modeling approach, runoff data were simulated from a real/hypothetical green roof based on real-world meteorological data that are essential to generate the runoff using the model. This study also developed a new simulation model to compare the effectiveness of extensive and semi-intensive green roofs in the reduction of rainfall-fed runoff. It is worth mentioning that limited studies have investigated the performance evaluation of semi-intensive green roofs. The proposed simulation study considers four different types of vegetation: grass/sedum, strawberry, mint, and cotton. The commonly used plant species for extensive and semi-intensive green roofs are sedum or grass lawns $[79,100,101]$, which have been considered for the simulation study as the base vegetation. Strawberry, as a fruit, mint, as a medicinal plant [102], and cotton, as a cash crop, were also considered to investigate their performance for flow reduction compared to the commonly used grass/sedum. It is imperative to mention that selection of the type of plant used for a green roof can greatly influence the aesthetic value [103] as well as other factors that may induce the interest of the communities to maintain the green roof. Various other co-benefits associated with green roofs, such as consuming the produce from the plants of the green roof for food [104] or using the plants for medicinal purposes or as a cash crop, can be obtained by using a different variety of vegetation. It can be noted that intensive green roofs were not considered in the simulation study, as the deployment of intensive green roofs generally requires a specific designing of the buildings and the rooftops [105]. Hence, the majority of residential buildings might not be suitable or lack the feasible provision for the deployment of an intensive green roof.

\subsection{Hydrological Performances of Green Roofs Observed in the Literature}

Performance evaluations for green roofs across the world were performed by either simulations based on hydrological models or by observations obtained using monitoring stations.

\subsubsection{Monitoring Methods for Green Roof Performance Evaluation}

A set of studies have estimated the effectiveness of green roofs in reducing the volume of flow by comparing them with situations without any green roofs. Both intensive and extensive green roofs have been considered in various studies [106,107]. The effect of vegetation types, such as sedum, meadow, stacys, or radix ophiopogonis, have also been considered by different studies, and intercomparison within the inflow reduction was observed $[79,100,101]$. Furthermore, the effect of soil thickness and soil moisture content (dry/wet soil) were also investigated for the performance evaluation of green roofs [108-110]. A few of those studies focused on individual storm events (minute/hourly/daily time scale), while others estimated the effectiveness of green roofs at monthly or seasonal (dry or wet season; summer or winter) or annual time scales $[77,88,111-113]$. Details on those studies are provided in Table A1 in Appendix A. The table summarizes information on the performance of green roofs, corresponding to types of rainfall events.

\subsubsection{Modeling Methods for Green Roof Performance Evaluation}

Few studies have considered hydrological models to simulate the effect of green roof inflow volume reduction. The Storm Water Management Model (SWMM) was found to be the most commonly used hydrological model for modeling the water cycle with green roofs [114-118]. However, models such as the Conceptual Hydrological Flux Model [119], HYDRUS-1D [120,121], MIKE-SHE [47], Modelling of Urban Sewers [122], Soil Conservation Service Curve Number [11,123], Sobek [124], System for Urban Stormwater Treatment and Analysis Integration [125], Soil Water Atmosphere and Plant [126], and SWMS-2D [127] has been in use by several researchers to simulate the effectiveness of green roofs. The majority of those models run at a minute/hourly scale and correspond to a given storm event; however, in some situations, the models were run for daily [125], monthly [126], or even annual [119] scales as well. The major advantage of the use of hydrological models is that 
several hypothetical scenarios, where a different portion of the buildings covering green roofs (single/collection of buildings; $20 \% / 25 \% / 50 \% / 100 \%$ of the area covered with green roofs) can be simulated and the increase in flow volume reduction, can be estimated $[47,116]$. One disadvantage of modeling is that, in certain situations, the effectiveness of those models needs to be evaluated through real-world monitored data. Currently, only a limited number of studies have shown model validation using monitored data $[114,127]$.

\subsection{Evaluating the Performance of Green Roofs Using a Simulation Study}

To assess the performance of green roofs, it is necessary to estimate the overall runoff and amount of water reduction. For this purpose, a simple water balance approach can be used, expressed as follows:

$$
R O=P-E T-\triangle S M C
$$

where $R O$ denotes the combined runoff from the overland flow and infiltrated water; $P$ is the observed precipitation; $E T$ is the evapotranspiration; and $\triangle S M C$ is the changes in soil moisture content. In this study, ET and $\triangle S M C$ are modeled/calculated, while $P$ is observed. Finally, $R O$ at each time step is estimated from Equation (1). All the terms in the equation are provided in depth per time unit. In this analysis, the time step is considered to be on a daily scale. A flowchart of the model is shown in Figure 2 and the details of the model are explained as follows:

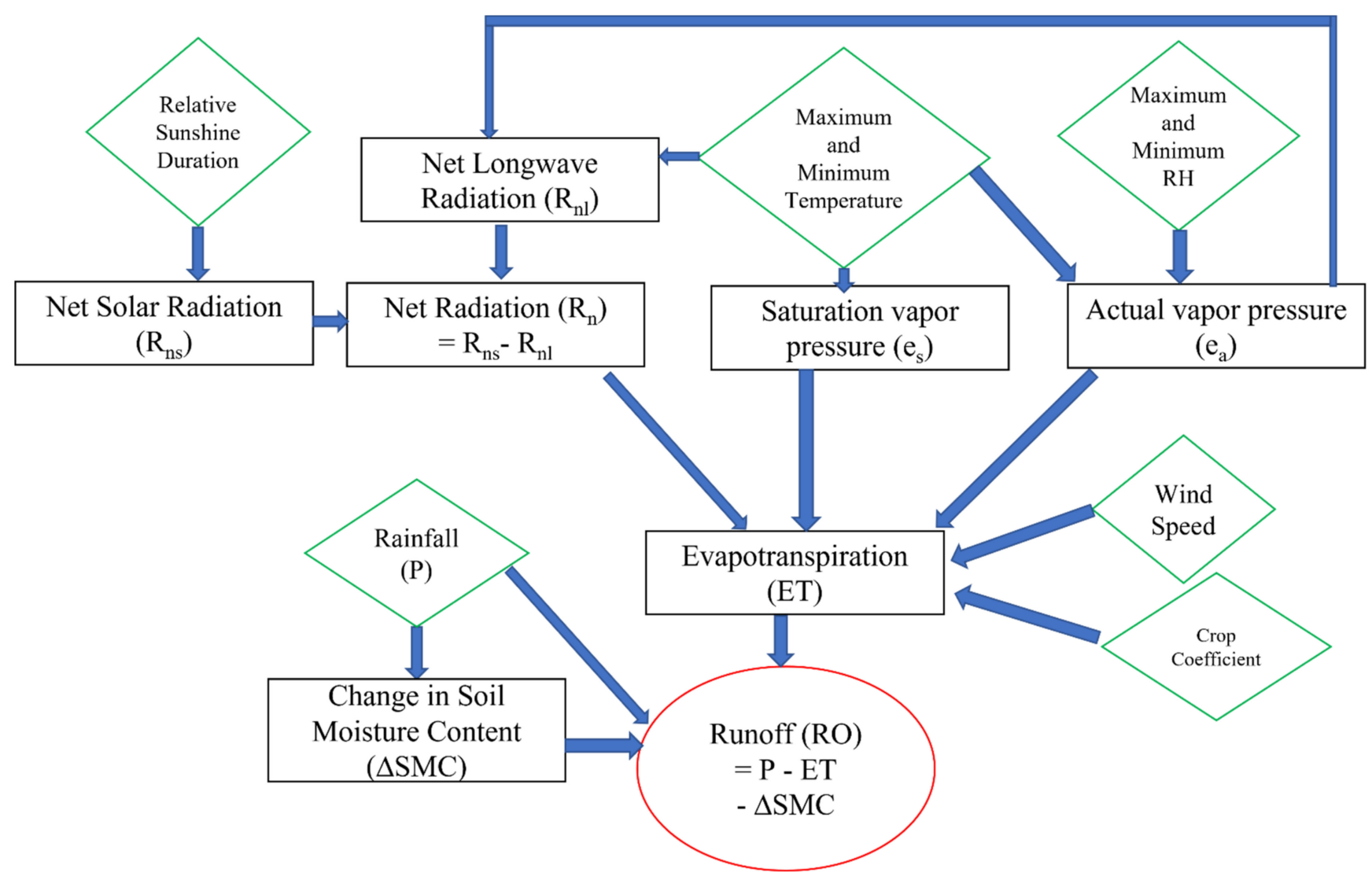

Figure 2. Flowchart of the simulation model for the estimation of daily runoff from green roofs. The input variables are shown using green rhombi, the intermediate variables estimated by the model are shown in black rectangles, while the final output of the model is shown in the red circle. 
The total runoff from the green roof $R O$ for a chosen day was considered to depend on the total precipitation that occurred on the given day, the total amount to evapotranspiration $E T$ on that day, and changes in soil moisture content (SMC) of the soil on the green roof. Increases in precipitation led to higher runoffs, while an increase in evapotranspiration reduced the runoff. A positive (negative) change in SMC indicated an increase (decrease) in soil moisture from the previous day. An increase in SMC indicated that the soil held more water, which led to a reduction in runoff from the green roof, and vice versa. Out of the three required variables, precipitation was measured using rain gauge sensors, while the evapotranspiration was estimated based on the Penman-Monteith method, whereas the changes in SMC was modeled using an approach proposed in this study. The model requires daily maximum, minimum, and average temperatures, daily maximum and minimum relative humidity, daily average wind speeds, and daily sunshine duration as inputs for the estimation of evapotranspiration. The actual evapotranspiration depends on the type of vegetation, quantified using a crop coefficient that varies with the crop type. The estimation of changes in soil moisture content requires the depth of soil strata. Precipitation is the source of rainfall-fed runoff, and was also used to estimate the soil moisture content.

\subsubsection{Precipitation}

The proposed model runs on a daily time scale, similar to Burszta-Adamiak and Mrowiec and Gao et al. [114,125], where the SWMM and SUSTAIN models were used, respectively, to investigate the effectiveness of green roofs in runoff reduction. The precipitation required to simulate the proposed model can be the observed rainfall for $24 \mathrm{~h}$.

\subsubsection{Model to Estimate Evapotranspiration}

As per the Food and Agriculture Organization (FAO) guidelines, the FAO PenmanMonteith method is recommended [128] to estimate the reference crop evapotranspiration $E T_{0}$, where the maximum possible evapotranspiration under standard conditions $E T_{\text {potential }}$ is a product of $E T_{0}$ and crop coefficient $K_{c}$ :

$$
E T_{\text {potential }}=K_{c} \times E T_{0}
$$

The standard condition denotes disease-free and well-fertilized crops with optimal soil-water conditions, whereas the considered reference crop is grass.

The advantage of the FAO Penman-Monteith method is that the model is physically based, can account for both physiological and aerodynamic parameters, and closely resembled experimental studies. Details of the FAO Penman-Monteith method to estimate reference crop evapotranspiration are provided below:

$$
E T_{0}=\frac{0.408 \Delta\left(R_{n}-G\right)}{\Delta+\gamma\left(1+0.34 u_{2}\right)}+\frac{\gamma[900 /(T+273)] u_{2}\left(e_{s}-e_{a}\right)}{\Delta+\gamma\left(1+0.34 u_{2}\right)}
$$

where $E T_{0}$ is the reference crop evapotranspiration $\left(\mathrm{mm} \mathrm{day}^{-1}\right) ; R_{n}$ is the net radiation at the crop surface ( $\left.\mathrm{MJ} \mathrm{m}^{-2} \mathrm{day}^{-1}\right) ; G$ is soil heat flux density ( $\left.\mathrm{MJ} \mathrm{m}{ }^{-2} \mathrm{day}^{-1}\right)$; $T$ is the mean daily air temperature at a $2-\mathrm{m}$ height $\left({ }^{\circ} \mathrm{C}\right) ; u_{2}$ is the wind speed at 2-m height $\left(\mathrm{m} \mathrm{s}^{-1}\right) ; e_{S}$ is the saturation vapor pressure $(\mathrm{kPa})$; and $e_{a}$ is the actual vapor pressure $(\mathrm{kPa})$, where $\left(e_{s}-e_{a}\right)$ is the saturation vapor pressure deficit $(\mathrm{kPa}) ; \Delta$ is the slope of the saturation vapor pressure-temperature curve $\left(\mathrm{kPa}^{\circ} \mathrm{C}^{-1}\right)$; and $\gamma$ is the psychrometric constant $\left(\mathrm{kPa}{ }^{\circ} \mathrm{C}^{-1}\right)$.

Estimation of Net Radiation $R_{n}$

The $R_{n}$ is the difference between the net radiation between short $\left(R_{n s}\right)$ and long wavelengths $\left(R_{n l}\right)$, given as:

$$
R_{n}=R_{n s}-R_{n l}
$$

where $R_{n s}\left(\mathrm{MJ} \mathrm{m}{ }^{-2}\right.$ day $^{-1}$ ) is the (incoming - outgoing) radiation for short wave (solar radiation) and $R_{n l}\left(\mathrm{MJ} \mathrm{m}{ }^{-2}\right.$ day $\left.^{-1}\right)$ is (outgoing - incoming) radiation for long waves. 
The net solar radiation $R_{n s}$ can be estimated as:

$$
R_{n s}=(1-\alpha) R_{s}
$$

where $\alpha$ is the albedo and $R_{S}$ is solar radiation $\left(\mathrm{MJ} \mathrm{m}^{-2}\right.$ day $\left.{ }^{-1}\right)$. In general, the albedo ranges between $0.2-0.25$ for green vegetation cover, and a value equal to 0.23 was considered for this study.

The solar radiation can be estimated using the following equation:

$$
R_{s}=\left(a_{s}+b_{s} \frac{n}{N}\right) R_{a}
$$

where $R_{a}\left(\mathrm{MJ} \mathrm{m}^{-2} \mathrm{day}^{-1}\right)$ is extra-terrestrial radiation, $n / N$ is the relative sunshine duration, and $a_{s}$ and $b_{s}$ are Angstrom coefficients taking values 0.25 and 0.5 , respectively. Relative sunshine duration expresses the cloudiness of the atmosphere as the ratio between the actual duration of sunshine $(n)$ and the maximum possible duration of sunshine or daylight hours $(N)$.

$R_{a}$ at a given latitude for a given day can be estimated as follows:

$$
R_{a}=\frac{24 \times 60}{\pi} G_{s c} d_{r}\left[\omega_{s} \sin (\varphi) \sin (\delta)+\cos (\varphi) \cos (\delta) \sin \left(\omega_{s}\right)\right]
$$

where $G_{S C}$ is solar constant equal to $0.0820 \mathrm{MJ} \mathrm{m}^{-2} \mathrm{~min}^{-1} ; d_{r}$ is the inverse relative distance Earth-Sun; $\omega_{S}$ is the sunset hour angle (radian); $\varphi$ is the latitude of the location (radian); and $\delta$ is the solar declination (radian). The terms in Equation (7) can be estimated as follows:

$$
d_{r}=1+0.033 \cos \left(\frac{2 \pi}{\text { Days }} J\right)
$$

where $J$ is the Julian day ranging from 1 (1 January) to 365 or 366 (31 December), and Days is either 365 (non-leap year) or 366 (leap year).

$$
\begin{gathered}
\delta=0.409 \sin \left(\frac{2 \pi}{D a y s} J-1.39\right) \\
\omega_{s}=\arccos [-\tan (\varphi) \tan (\delta)]
\end{gathered}
$$

The net longwave radiation $R_{n l}\left(\mathrm{MJ} \mathrm{m}^{-2}\right.$ day $\left.^{-1}\right)$ can be estimated based on the StefanBoltzmann law as:

$$
R_{n l}=\sigma\left[\frac{\left(T_{\max , \mathrm{K}}\right)^{4}+\left(T_{\min , \mathrm{K}}\right)^{4}}{2}\right]\left(0.34-0.14 \sqrt{e_{a}}\right)\left(1.35 \frac{R_{s}}{R_{s o}}-0.35\right)
$$

where $\sigma$ is the Stefan-Boltzmann constant $\left(=4.903 \times 10^{-9} \mathrm{MJ} \mathrm{K}^{-4} \mathrm{~m}^{-2}\right.$ day $\left.^{-1}\right) ; T_{\text {max }, K}$ is the observed maximum absolute temperature over $24-\mathrm{h}(\mathrm{K}) ; T_{\min , \mathrm{K}}$ is the observed minimum absolute temperature over $24-\mathrm{h}(\mathrm{K}) ; R_{s o}$ is the clear-sky radiation $\left(\mathrm{MJ} \mathrm{m}^{-2}\right.$ day $\left.^{-1}\right)$; and $e_{a}$ and $R_{s}$ are defined earlier. The clear-sky radiation can be estimated as:

$$
R_{s o}=\left(a_{s}+b_{s}\right) R_{a}
$$

based on Equation (6) by considering $n=N$.

\section{Estimation of Soil Heat Flux Density G}

As per the guidelines of the FAO [128], the soil heat flux density $G$ at the daily scale is relatively small and can be ignored, i.e.,

$$
G_{\text {daily }} \approx 0
$$




\section{Estimation of Mean Daily Air Temperature T}

The mean daily temperature can be estimated as the average of the maximum and the minimum air temperature observed over $24 \mathrm{~h}$ at a $2-\mathrm{m}$ height.

Estimation of Wind Speed at 2-m Height $u_{2}$

To estimate the reference crop evapotranspiration using the FAO Penman-Monteith method (Equation (3)), the anemometer needs to be located at a height of two meters from the vegetated surface [128]. In situations where the wind speed was recorded at $z_{0}$ meters altitude instead of a 2-m height, the wind speed at $2 \mathrm{~m} u_{2}$ can be estimated from the recorded wind speed $u_{z_{0}}$ by assuming a logarithmic wind speed profile as

$$
u_{2}=u_{z_{0}} \frac{4.87}{\ln \left(67.8 z_{0}-5.42\right)}
$$

Estimation of Saturation Vapor Pressure $e_{S}$

The mean saturation vapor pressure can be estimated based on the 24-h maximum $T_{\max }\left({ }^{\circ} \mathrm{C}\right)$ and minimum $T_{\min }\left({ }^{\circ} \mathrm{C}\right)$ temperatures as,

$$
e_{s}=\left[e^{o}\left(T_{\max }\right)+e^{o}\left(T_{\min }\right)\right] / 2
$$

where,

$$
e^{o}(T)=0.6108 \exp \left[\frac{17.27 T}{T+237.3}\right]
$$

Estimation of Actual Vapor Pressure $e_{a}$

The actual vapor pressure can be estimated based on the maximum and minimum observed relative humidity $R H_{\max }$ and $R H_{\text {min }}$, respectively:

$$
e_{a}=\frac{\left[e^{o}\left(T_{\max }\right) \frac{R H_{\min }}{100}+e^{o}\left(T_{\min }\right) \frac{R H_{\max }}{100}\right]}{2}
$$

Estimation of the Slope of the Saturation Vapor Pressure-Temperature Curve $\Delta$

$$
\Delta=\frac{4098\left[0.6108 \exp \left(\frac{17.27 T}{T+237.3}\right)\right]}{(T+237.3)^{2}}
$$

where $T$ is the mean daily temperature in ${ }^{\circ} \mathrm{C}$.

Estimation of Psychrometric Constant $\gamma$

The psychrometric constant can be estimated as

$$
\gamma=\frac{c_{p} p}{\varepsilon \lambda}
$$

where $c_{p}$ is the specific heat at constant pressure $\left(=1.013 \times 10^{-3} \mathrm{MJ} \mathrm{kg}^{-1}{ }^{\circ} \mathrm{C}^{-1}\right)$; $p$ is atmospheric pressure $(\mathrm{kPa}) ; \varepsilon$ is the molecular weight ratio of water vapor/dry air $(=0.622)$; and $\lambda$ is the latent heat of vaporization $\left(=2.45 \mathrm{MJ} \mathrm{kg}^{-1}\right)$. The atmospheric pressure can be estimated as

$$
p=101.3\left(\frac{293-0.0065 z}{293}\right)^{5.26}
$$

where $z$ is the elevation above sea level (meters).

\subsubsection{Method to Estimate Changes in Soil Moisture Content and Runoff}

To estimate the change in soil moisture content between two successive time steps (day), this study developed a new concept by assuming that if a given day is a non-rainy day, 
then the available soil moisture from the previous day will either be completely utilized by the vegetation through evapotranspiration, or any excess water will be percolated through the soil and contribute to runoff within a period of $24 \mathrm{~h}$. Since the soil depth is extremely shallow for this study $(80-150 \mathrm{~mm})$, this assumption can be considered acceptable. A similar assumption has been considered by Soulis et al. [74]. Furthermore, it can be considered that overland runoff will be generated only when the soil becomes fully saturated. Based on the assumption, one of the following scenarios should occur, where $S M C_{t-1}$ and $S M C_{t}$ are the soil moisture content of the previous and current day, respectively, and

$$
\triangle S M C=S M C_{t}-S M C_{t-1}
$$

where $E T_{\text {potential }}$ is the maximum possible value of evapotranspiration on a given day, considering sufficient water is available, and $S M C_{\text {saturated }}$ is the maximum possible soil moisture content during saturation. The value of $E T_{\text {potential }}$ for a day can be estimated using Equation (2), while the actual evapotranspiration in the simulation study can be estimated based on the equations provided below:

(a) Non-rainy day $(P=0)$ :

The case I: If $E T_{\text {potential }} \geq S M C_{t-1}$ :

$$
E T=S M C_{t-1}, S M C_{t}=0, R O=0
$$

Case II: If $E T_{\text {potential }}<S M C_{t-1}$ :

$$
E T=E T_{\text {potential }}, S M C_{t}=0, R O=S M C_{t-1}-E T_{\text {potential }}
$$

(b) Rainy day $(P>0)$ :

The case I: If $E T_{\text {potential }} \geq P+S M C_{t-1}$ :

$$
E T=P+S M C_{t-1}, S M C_{t}=0, R O=0
$$

Case II: If $E T_{\text {potential }}<P+S M C_{t-1}$ :

$$
\begin{gathered}
E T=E T_{\text {potential }} \\
\left.\begin{array}{c}
S M C_{t}=P+S M C_{t-1}-E T \\
R O=0 \\
S M C_{t}=S M C_{\text {saturated }} \\
\begin{array}{c}
P+S M C_{t-1}-E T-S M C_{\text {saturated }}
\end{array}
\end{array}\right\} \text { if }\left(P+S M C_{t-1}-E T\right) \leq S M C_{\text {saturated }} \\
\text { if }\left(P+S M C_{t-1}-E T\right)>S M C_{\text {saturated }}
\end{gathered}
$$

\subsubsection{Simulation Study}

An investigation of the effectiveness of green roofs in reducing runoff was carried out using a simulation study based on the approach described in Equation (1) and Sections 4.2.1-4.2.3. To run the simulation model for an estimation of runoff reduction using extensive/semi-intensive green roofs with different types of vegetation, five observed meteorological variables, namely, precipitation, temperature, wind speed, relative humidity, and relative sunshine duration, are required. A hypothetical green roof located in Dublin, Ireland was considered to conduct the aforementioned simulation study. Dublin is considered to exhibit a higher flood-risk due to urbanization [129-131]. The data for the meteorological variables at an hourly scale were obtained from MET Eireann [132] weather station, located at Dublin airport at $73 \mathrm{~m}$ altitude from the mean sea level for the period 1 January 1990, 12 AM, to 1 March 2020, 12 AM. The location of the weather station is shown in Figure 3. 




Figure 3. Location of Dublin Airport weather station. 
Following this, the daily total precipitation, daily maximum and minimum temperatures and relative humidity, daily mean wind speeds, and daily relative sunshine duration were estimated from the hourly data. The hourly as well as daily time series data of each of those meteorological variables except sunshine duration are provided in Figure 4. Based on the observed meteorological data and the figures, it can be noted that around $60.23 \%$ of days in the selected time period (1 January 1990 to the end of 29 February 2020, comprising 11,017 days) were non-rainy, while the remaining $39.77 \%$ of days exhibited rainfall. The average rainfall in the rainy days was found to be $3.51 \mathrm{~mm} /$ day, while the maximum recorded rainfall intensity in the selected period was $26.5 \mathrm{~mm} /$ hour. Out of the 11,017 days considered in the simulation study, 539 days $(\sim 4.89 \%)$ had rainfalls greater than $10 \mathrm{~mm}, 120$ days $(\sim 1.09 \%)$ had rainfalls greater than $20 \mathrm{~mm}$, whereas 44 days $(\sim 0.4 \%)$, 18 days $(0.16 \%)$, and 6 days $(\sim 0.05 \%)$ had more than $30 \mathrm{~mm}, 40 \mathrm{~mm}$, and $50 \mathrm{~mm}$ of rainfall, respectively. The temperature was found to vary considerably throughout the year in Dublin. The range of recorded daily maximum temperatures was found to vary from -4.9 to $28.5^{\circ} \mathrm{C}$, while the range for daily minimum temperatures was -11.5 to $18.8^{\circ} \mathrm{C}$, with a mean temperature of $9.76^{\circ} \mathrm{C}$. Around $2.11 \%$ days recorded temperatures below $0{ }^{\circ} \mathrm{C}$. The relative humidity ranged from $25-100 \%$; however, the average relative humidity was $82.96 \%$. The average wind in the city was $5.43 \mathrm{~m} / \mathrm{s}(\sim 19.54 \mathrm{kmph})$, and the highest recorded wind speed was $23.15 \mathrm{~m} / \mathrm{s}(\sim 83.34 \mathrm{kmph})$. Furthermore, the average sunshine duration was found to be around $4.01 \mathrm{~h}$. Overall, the meteorological data indicate that the city was humid, exhibited high wind, moderate precipitation, and relatively low sun exposure, and that the temperature did not rise above $30^{\circ} \mathrm{C}$ in the summertime, while only $7-8$ days in winter $(\sim 2 \%)$ recorded temperatures below $0{ }^{\circ} \mathrm{C}$.
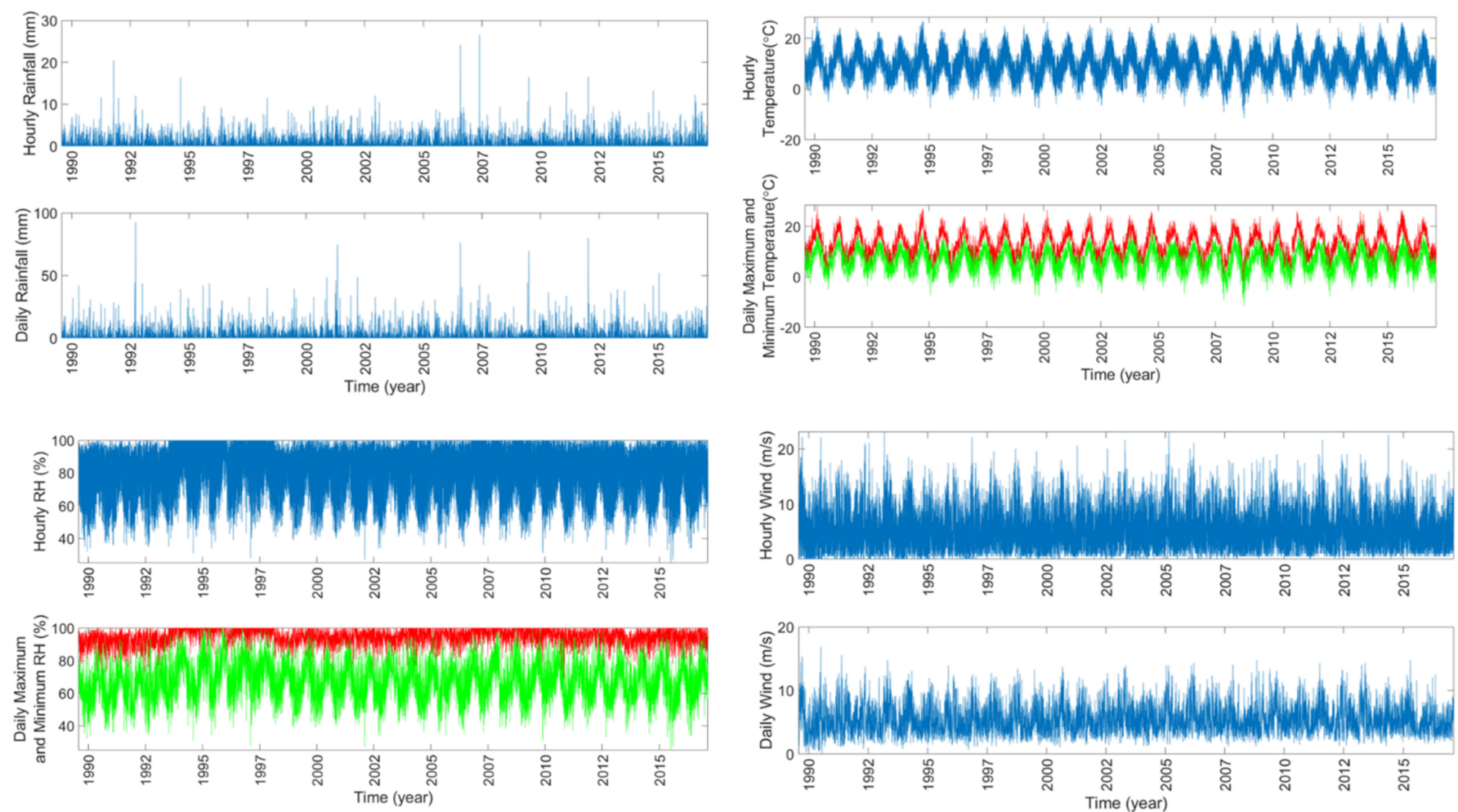

Figure 4. Hourly and daily time series plots of precipitation, temperature, relative humidity, and mean wind speed.

Four different types of vegetation were considered to investigate their performance in flood mitigation. The vegetation was (a) grass/sedum, (b) strawberries, (c) mint, and (d) cotton. The crop coefficients for those vegetations were 1.0, 0.75, 1.1, and 0.5, respectively [128]. Two different soil depths of $80 \mathrm{~mm}$ (shallow) and $150 \mathrm{~mm}$ (medium) were considered for this simulation study to estimate green roof performance. The shallow-depth 
hypothetical roof was a representation of the extensive green roof, while the medium-depth roof replicated semi-intensive green roofs. Clay was considered as the soil type, and the available water content for the soil was considered to be $175 \mathrm{~mm}$ per one-meter soil depth, as per the FAO guidelines [133]. Subsequently, simulations were performed to estimate evapotranspiration, changes in soil moisture content, and runoff on a daily scale.

Runoff from the green roof at a daily time scale was simulated using the simulation model described in Sections 4.2.1-4.2.3. The daily values of reference crop evapotranspiration $E T_{0}$ were estimated based on the daily average, the maximum and minimum temperature, the daily maximum and minimum relative humidity, the daily average wind speed, the and daily sunshine duration values. The time series plot of $E T_{0}$ is shown in Figure 5. The actual evapotranspiration $E T$ varies with the vegetation type, soil depth, precipitation, and soil moisture content. In this simulation study, eight combinations of vegetation types and soil depths (four types of vegetation and two different soil depths) were used to simulate the actual evapotranspiration and the corresponding runoff from the green roof. For comparison, the runoff was compared to the expected runoff without the presence of green roofs. In situations where the green roof was not available, the runoff will be equal to the precipitation excluding evaporation. The evaporation was estimated using the combined aerodynamic and energy balance method [134]. Subsequently, the difference in the runoff with and without the green roof was estimated at a daily time period for each of the eight green roof cases.



Figure 5. Reference crop evapotranspiration time series plot at daily scale using Penman-Monteith method.

Reductions in runoff due to the green roof on days exhibiting greater than $50 \mathrm{~mm}$, $40 \mathrm{~mm}, 30 \mathrm{~mm}, 20 \mathrm{~mm}$, and $10 \mathrm{~mm}$ precipitation were obtained in terms of percentage and are shown in Table 1. Scatterplots of runoff without and with the green roofs are shown in Figure 6, where the runoffs without the green roof are plotted along the horizontal axis and the runoffs from the green roof are plotted along the vertical axis as points. Each point in the figure denotes the daily runoff obtained based on the simulation study. The 1:1 line, shown in cyan, indicates that points in that line would have the same runoff with and without the green roof, while points falling below the line indicate a reduction in runoff due to the green roof. Each figure was segregated by considering only those days where rainfall is greater than $10 \mathrm{~mm}, 20 \mathrm{~mm}, 30 \mathrm{~mm}, 40 \mathrm{~mm}$, and $50 \mathrm{~mm}$, respectively. Furthermore, runoff from each of the eight green roofs was shown in the figures. The figures clearly 
indicate that the reduction in runoff increases with an increase in soil depth and that mint is most effective, compared to other vegetation.
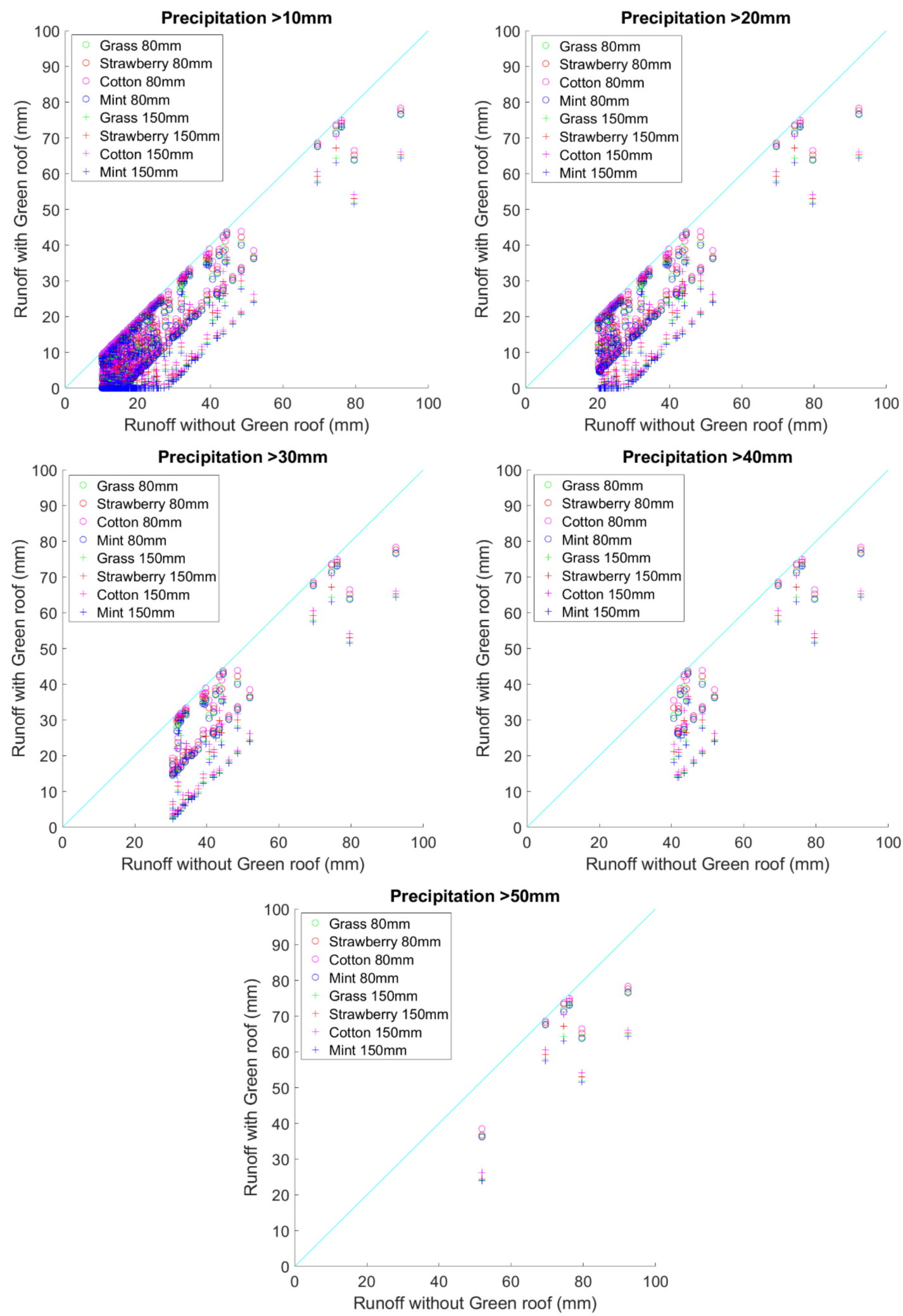

Figure 6. Scatterplot of runoff with and without green roof in millimeters. Points falling along the 1:1 line, shown in cyan, indicate no change in runoff with and without green roofs, while points below (above) the line indicate reduction (increase) in runoff with the green roof. 
Table 1. Percentage reduction in runoff due to the green roof with varying soil depths and vegetation.

\begin{tabular}{|c|c|c|c|c|c|c|c|}
\hline \multicolumn{3}{|c|}{ Precipitation } & \multirow{2}{*}{$\begin{array}{c}>50 \mathrm{~mm} \\
6\end{array}$} & \multirow{2}{*}{$\begin{array}{c}>40 \mathrm{~mm} \\
18\end{array}$} & \multirow{2}{*}{$\begin{array}{c}>30 \mathrm{~mm} \\
44\end{array}$} & \multirow{2}{*}{$\begin{array}{c}>20 \mathrm{~mm} \\
120\end{array}$} & \multirow{2}{*}{$\begin{array}{c}>10 \mathrm{~mm} \\
539\end{array}$} \\
\hline Numbe & of Days & $\begin{array}{c}\text { Crop } \\
\text { Coefficient }\end{array}$ & & & & & \\
\hline \multirow{4}{*}{$\begin{array}{l}\text { Shallow soil } \\
\quad(80 \mathrm{~mm})\end{array}$} & Grass/Sedum & 1.0 & 12.10 & 18.23 & 23.94 & 32.77 & 55.09 \\
\hline & Strawberries & 0.75 & 11.01 & 16.38 & 21.87 & 29.97 & 51.40 \\
\hline & Cotton & 0.5 & 9.80 & 14.69 & 19.96 & 27.12 & 47.61 \\
\hline & Mint & 1.1 & 12.53 & 18.96 & 24.80 & 33.92 & 56.57 \\
\hline \multirow{4}{*}{$\begin{array}{l}\text { Medium soil } \\
\quad(150 \mathrm{~mm})\end{array}$} & Grass/Sedum & 1.0 & 24.31 & 38.50 & 47.38 & 60.48 & 77.21 \\
\hline & Strawberries & 0.75 & 22.68 & 36.37 & 44.69 & 57.41 & 74.57 \\
\hline & Cotton & 0.5 & 20.64 & 34.03 & 42.27 & 54.51 & 71.87 \\
\hline & Mint & 1.1 & 24.91 & 39.33 & 48.60 & 61.75 & 78.21 \\
\hline
\end{tabular}

The reason for considering only those days with higher rainfall ( $>10 \mathrm{~mm}-50 \mathrm{~mm})$ is that the goal of the green roof is to reduce runoff in situations with a higher probability of flooding. It can be noted from the table that the percentage reduction in the runoff increases when the minimum rainfall amount considered is lowered. This can be attributed to the fact that on those days where there is less rainfall, the total/majority of the rainfall is either being stored in the soil as soil moisture content or is contributing to evapotranspiration. The reduction in runoff is the minimum for days having the highest precipitation, as the soil becomes fully saturated and is unable to hold any further water, and evapotranspiration reaches its maximum value, leading to high runoff (overland and/or infiltrated). Reduction in runoff is found to be higher with more soil depth on rainy days. This is because the water-holding capacity of soil increases with an increase in soil depth, as thicker soil can hold more water during a rainfall event leading to a reduction in peak runoff and a delay in the peak. However, it needs to be noted that the extra amount of water stored in the soil will eventually contribute to infiltrated runoff for a longer duration, ensuring the total runoff is the same for both shallow and medium soil depths. In terms of the types of vegetation considered in this study, the mint was found to have the highest efficiency in the reduction of runoff, followed by grass, strawberries, and cotton. This is attributed to higher crop coefficient values and subsequently higher evapotranspiration.

\subsubsection{Real-World Case Study}

The effectiveness of the developed model has been estimated based on a real-world case study conducted in Dublin, Ireland. A green roof was deployed in the CHQ building located at the city center in Dublin for the study. The green roof was deployed in February 2021 and had a total size of $70 \mathrm{sq}$. m. The green roofs consisted of 70 modular units, each having an area of 1 sq. m, and are shown in Figure 7a. The vegetation cover used for the green roof was sedum. In order to evaluate the effectiveness of the green roofs in runoff reduction, a set of weather variables were measured from 21 February 2021 to 28 February 2021. The variables considered were rainfall, temperature, wind speed, relative humidity, and sunshine hours. They were measured using a set of sensors installed on the roof of the $\mathrm{CHQ}$ buildings located adjacent to the deployed green roofs. The rainfall was measured using a rain gauge sensor and the temperature was measured using a temperature sensor, while the other three meteorological variables were measured using weather stations installed on the roof of the $\mathrm{CHQ}$ building. The rainfall and temperature were measured at 10-min time intervals and the other three variables (wind speed, relative humidity, and sunshine hours) were measured at an hourly scale. To estimate the reduction in runoff from the green roofs, four modular roofs were considered in this study. The weight of each of those modular roofs was measured at 10-min intervals using IoT weight sensors. 
Changes in the weight of the modular trays were used to estimate the runoff from the green roof. The weight of the modular tray along with the green roof is shown in Figure $7 \mathrm{~b}$.

(a)
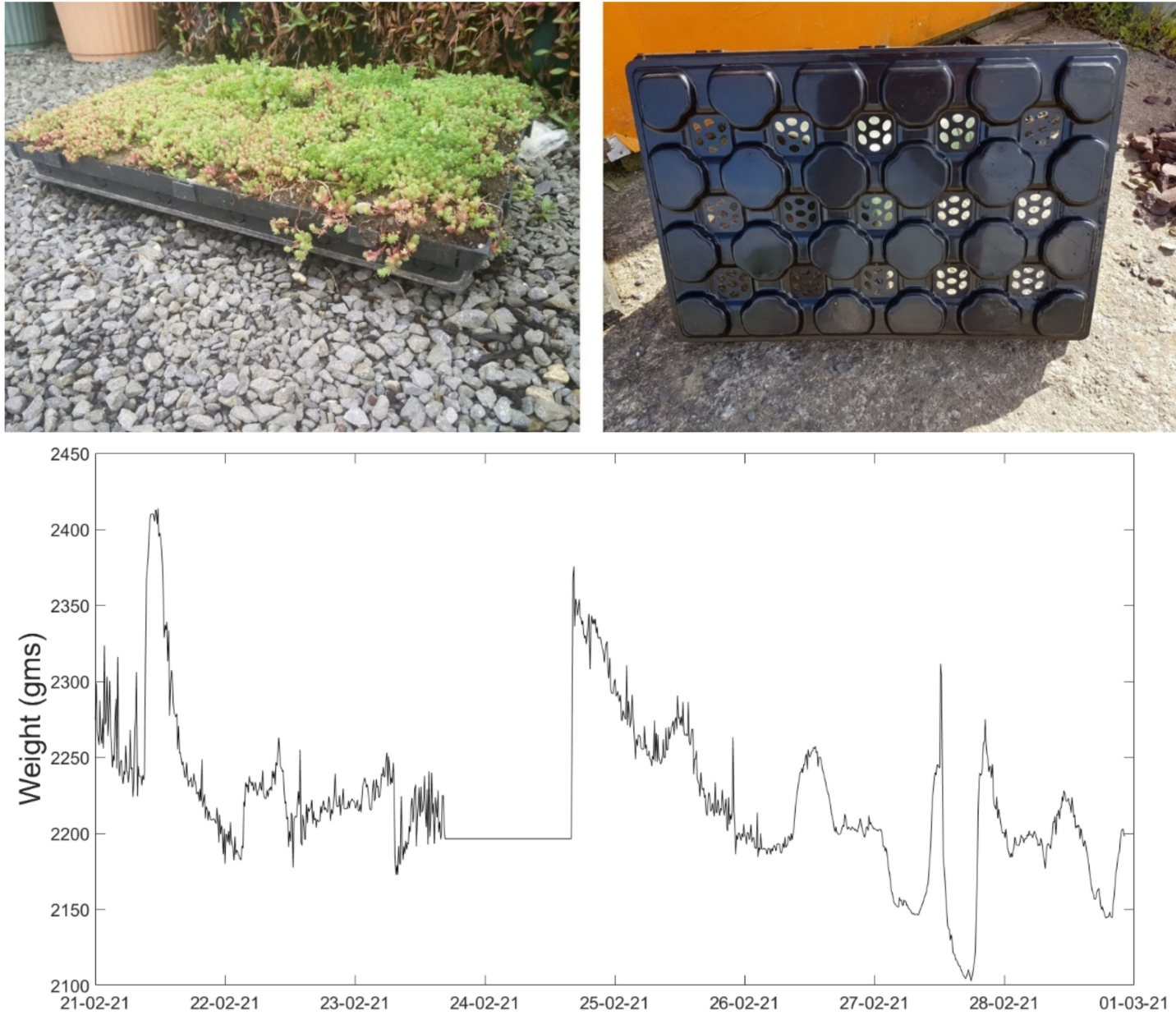

(b)

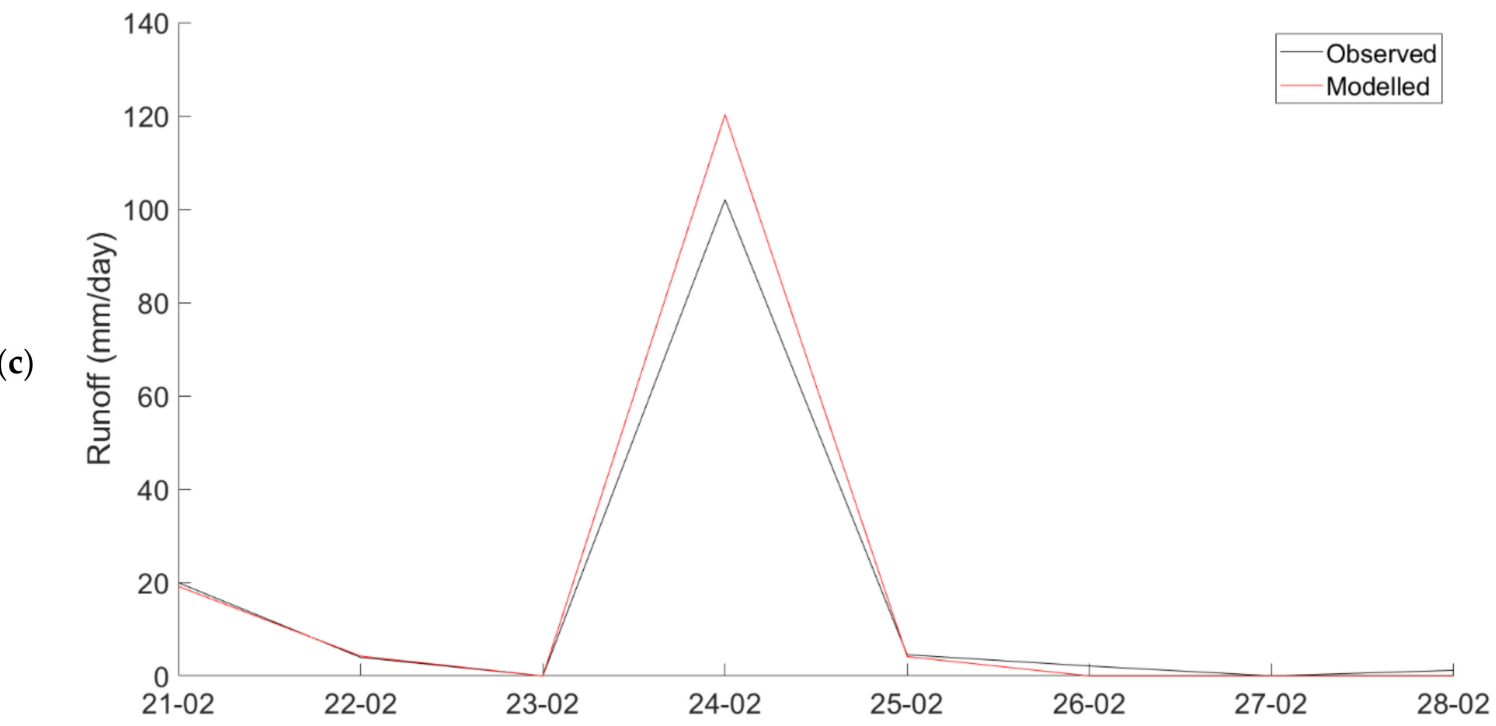

Figure 7. (a) Modular green roof tray used at CHQ building in Dublin; (b) Time series plot of the weight of modular tray; (c) Runoff from the green roof modular tray obtained, based on observations and the simulation model. 
Based on the measured weather variables, the runoff from the green roof was simulated for the selected duration using the proposed model given in Equation (1). Comparisons of the modeled runoff and the measured runoff are shown in Figure 7c. The differences in runoff obtained using measured data and the modeled output were quantified by using three statistical measures:

(a) Nash-Sutcliffe Efficiency (NSE):

$$
N S E=1-\frac{\sum_{t=1}^{T}[\hat{y}(t)-y(t)]^{2}}{\sum_{t=1}^{T}[y(t)-\bar{y}]^{2}}
$$

where $y(t)$ is the observed runoff at time $t, \hat{y}(t)$ is the model predicted runoff at time $t, T$ is the number of daily data points, and $\bar{y}=\sum_{t=1}^{T} y(t) / T$ is the mean observed runoff.

(b) Pearson correlation coefficient (CORR):

$$
\operatorname{CORR}=\frac{T \sum_{t=1}^{T} \hat{y}(t) \times y(t)-\left[\sum_{t=1}^{T} \hat{y}(t)\right] \times\left[\sum_{t=1}^{T} y(t)\right]}{\sqrt{\left[T \sum_{t=1}^{T}(\hat{y}(t))^{2}-\left(\sum_{t=1}^{T} \hat{y}(t)\right)^{2}\right] \times\left[T \sum_{t=1}^{T}(y(t))^{2}-\left(\sum_{t=1}^{T} y(t)\right)^{2}\right]}}
$$

(c) Kling-Gupta Efficiency (KGE):

$$
K G E=1-\sqrt{(\operatorname{CORR}-1)^{2}+(a-1)^{2}+(b-1)^{2}}
$$

where CORR is the Pearson correlation coefficient, $a=\sqrt{\frac{T \sum_{t=1}^{T}(\hat{y}(t))^{2}-\left(\sum_{t=1}^{T} \hat{y}(t)\right)^{2}}{T \sum_{t=1}^{T}(y(t))^{2}-\left(\sum_{t=1}^{T} y(t)\right)^{2}}}$, and $b=\sqrt{\frac{\sum_{t=1}^{T} \hat{y}(t)}{\sum_{t=1}^{T} y(t)}}$.

The value of NSE and KGE ranges from $(-\infty, 1)$, while CORR ranges from $(-1,1)$. The values of all three error measures, NSE, KGE, and CORR, tend to unity as model predictions become closer to the observed values.

A comparison of the time series plots of measured and modeled runoff (Figure 7c) indicates that the model slightly overpredicts the peak runoff and underpredicts the low runoff. However, the differences between the observed and modeled predicted runoffs are considerably low. The values of the statistical measures are: NSE $=0.961, C O R R=0.999$, and $K G E=0.806$. All three measures are sufficiently close to unity. The results indicate that the proposed model can be used to simulate the runoff from a green roof at a daily time scale.

\section{Discussion and Conclusions}

This paper focused on the assessment of the performance of a green roof system for controlling flood risk. To achieve this, a new innovative simulation model has been proposed to evaluate the extent to which the green roof can maximize flood risk reduction. The extensive literature review has shown a current trend where there is a shift of focus from artificial (gray) flood mitigation systems to a natural and sustainable systems (green/blue solutions). It is imperative to investigate the effectiveness of green roofs by using a combination of realistic models and real-world monitored data to understand the water cycle dynamics. The primary goal of the simulation study is to understand the dynamics of the rainfall-runoff system with and without the presence of a nature-based solution, which can help with deciding on the type of NBS that might be suitable for realworld deployment. The developed model is a function of rainfall intensity and duration at the daily timescale, for vegetation type, soil depth, and soil moisture content. Since the proposed model considers the daily time scale, it can be used for long-term performance evaluations of green roofs. The developed model has been validated by considering one 
week's data obtained from a green roof deployed in the CHQ building located at the city center of Dublin, Ireland. The green roof was deployed in February 2021, and, at present, only limited data has been made available. Longer weather data will be collected in the near future, once the restrictions due to COVID-19 are lifted. The performance of the proposed model in different weather conditions with varying intensities, and durations of rainfall, temperatures, and wind speeds need to be evaluated. Ongoing research focuses on collecting data from the green roof for this purpose. A good amount of data, once gathered from the green roof pilot, can give us precise information about urban flooding. Furthermore, it needs to be noted that since the time interval of the proposed model is at a daily scale, the model cannot be used to estimate runoff from a green roof at hourly/sub-hourly time scales. In situations where the focus is on individual storm events occurring over a short time period, the changes in rainfall intensity within the short time period and the duration of the storm event will become important. A different model needs to be developed to simulate runoff at a finer time scale. Current research is focusing on the development of another green roof model for Dublin based on the real-world measurements collected at the CHQ building in Dublin. The objective of the new model would be to account for its effectiveness in every individual storm event where the runoff is simulated at an hourly/sub-hourly time scale.

The information from this type of study would be valuable for the identification of optimal locations for the placement of the green roofs, and will help with designing a robust green-roof structure efficiently and economically. Based on this analysis, it has been noted that, to achieve a considerable reduction of rainfall-fed runoff (pluvial flooding), green roofs need to be deployed at multiple locations across the urban area. An effective system of green roofs has the potential to develop a robust flood-control network.

The deployment of the green roof has been evident in several highly urbanized locations, where green strategies have been undertaken for the implementation of green roofs. One such example is the deployment of a green roof in Singapore. To build trust in the green roof system, standardized support and general principles for planning, design, execution, and maintenance were aligned with the best practices [135]. Various ecological compensation and other financial incentives can be considered at a broader scale to increase the uptake of green roofs. Nature-based enterprises and organizations can be leveraged to deliver the upscaled deployment of green roofs in cities [136].

Author Contributions: Conceptualization, A.S.B.; methodology, A.S.B., S.S. and B.B.; validation, A.S.B. and F.P.; formal analysis, A.S.B.; writing-original draft preparation, A.S.B., F.P., S.S., R.G., A.G. and B.B.; writing-review and editing, A.S.B. and F.P.; visualization, A.S.B.; supervision, F.P.; funding acquisition, F.P. All authors have read and agreed to the published version of the manuscript.

Funding: This research was funded by the EUROPEAN UNION HORIZON 2020 project OPERANDUM (OPEn-air laboRAtories for Nature baseD solUtions to Manage hydro-meteo risks), grant number 776848 .

Institutional Review Board Statement: Not applicable.

Informed Consent Statement: Not applicable.

Data Availability Statement: Data used for conducting the simulation analysis in this study are publicly available from the following link: https: / /www.met.ie/climate/available-data/historicaldata accessed on 24 November 2021.

Conflicts of Interest: The authors declare no conflict of interest. 


\section{Appendix A}

Table A1. Hydrological performances of green roofs. (CHFM: Conceptual Hydrological Flux Model; MOUSE: Modeling of Urban Sewers; SCS-CN: Soil Conservation Service Curve Number; SUSTAIN: System for Urban Stormwater Treatment and Analysis Integration; SWAP: Soil Water Atmosphere and Plant; SWMM: Storm Water Management Model; NA: Not Available).

\begin{tabular}{|c|c|c|c|c|c|c|}
\hline S1 & $\begin{array}{l}\text { Location and } \\
\text { Analysis Type }\end{array}$ & $\begin{array}{c}\text { Size of } \\
\text { Study Area }\end{array}$ & Details of Weather/Climate & $\begin{array}{c}\text { Green roof } \\
\text { Details/Percentage } \\
\text { Improvement }\end{array}$ & Findings & Ref. \\
\hline 1 & $\begin{array}{c}\text { Georgia, USA } \\
\text { Monitoring }\end{array}$ & 42.64 sq. meter & $\begin{array}{l}31 \text { individual storm events } \\
\text { from Nov 2003-Nov 2004, } \\
\text { where precipitation depth } \\
\text { ranged from } 0.28 \text { to } 8.43 \mathrm{~cm} \text {. }\end{array}$ & $\begin{array}{l}\text { Green roof stormwater } \\
\text { retention ranged from } \\
39-100 \% \text {, with an average } \\
\text { retention just under } 78 \% \text {. } \\
\text { In situations where } \\
\text { precipitation was less than } \\
1.27 \mathrm{~cm}, \text { more than } 90 \% \\
\text { times the green roof } \\
\text { effectively retain entire } \\
\text { water. However, during a } \\
5.38 \mathrm{~cm} \text { storm event } \\
\text { occurring on November } 19 \text {, } \\
2003 \text {, the green roof } \\
\text { managed to retain } 39 \% \\
\text { water, which is the least } \\
\text { retention over all the } \\
31 \text { storm events. }\end{array}$ & $\begin{array}{l}\text { The green roof mostly retained } \\
\text { the rainfall from the frequently } \\
\text { occurring to small amount of } \\
\text { storm events. In urbanized } \\
\text { areas, little rainfall infiltrates, } \\
\text { resulting in slow stream base } \\
\text { flow; most of the water is } \\
\text { transported and results in } \\
\text { elevated stormflow. } \\
\text { Stormwater retention can occur } \\
\text { at the beginning of storms as the } \\
\text { substrate medium absorb the } \\
\text { rainfall until saturation point is } \\
\text { reached. The green roof operates } \\
\text { as a retention instrument for a } \\
\text { particular water volume. } \\
\text { The occurrence of retention } \\
\text { depends on seasonal factors } \\
\text { when the substrate later is thin. }\end{array}$ & [88] \\
\hline
\end{tabular}

\begin{tabular}{|c|c|c|c|c|c|c|}
\hline 2 & $\begin{array}{l}\text { Brussels, } \\
\text { Belgium } \\
\text { Monitoring }\end{array}$ & NA & $\begin{array}{l}628 \text { individual storm events } \\
\text { with rainfall intensity } \\
\text { ranging from } \\
27.8-300 \mathrm{~mm} / \mathrm{h} .\end{array}$ & $\begin{array}{l}\text { A total of } 11 \text { intensive green } \\
\text { roofs were considered in the } \\
\text { study with substrate layer } \\
\text { depths ranging from } \\
150-350 \mathrm{~mm} \text {. Reduction in } \\
\text { runoff varied from } 65-85 \% \text {. } \\
\text { A total of } 121 \text { extensive } \\
\text { green roofs were studied, } \\
\text { having } 30-140 \text { mm depths. } \\
\text { Runoff reduction ranged } \\
\text { from } 27-81 \% \text {, depending on } \\
\text { storm events. }\end{array}$ & $\begin{array}{l}\text { Retention in the green roof is } \\
\text { greater in summer compared to } \\
\text { winter. This result is due to } \\
\text { differences in rainfall } \\
\text { distribution and } \\
\text { evapotranspiration. }\end{array}$ & [76] \\
\hline 3 & $\begin{array}{l}\text { Pittsburg, USA } \\
\text { Monitoring }\end{array}$ & 1115 sq. meter & $\begin{array}{c}\text { Average annual } \\
\text { precipitation of } 0.94 \mathrm{~m} .\end{array}$ & $\begin{array}{l}\text { Annual average runoff } \\
\text { reductions for extensive } \\
\text { green roofs were up to } 60 \% \text {, } \\
\text { and for intensive green } \\
\text { roofs were up to } 85 \% \text {. }\end{array}$ & $\begin{array}{l}\text { This paper focuses on the } \\
\text { co-benefits of the green roof } \\
\text { through a life cycle assessment. }\end{array}$ & [106] \\
\hline 4 & $\begin{array}{l}\text { Michigan, } \\
\text { USA } \\
\text { Monitoring }\end{array}$ & 5.954 sq. meter & $\begin{array}{l}\text { A total of } 62 \text { individual } \\
\text { storm events observed } \\
\text { between } 26 \text { April } \\
\text { 2005-1 September } 2006 \text { were } \\
\text { considered for the analysis. } \\
\text { The storm events were } \\
\text { categorized into } 16 \text { light } \\
(<2 \mathrm{~mm}), 24 \text { medium } \\
(2-10 \mathrm{~mm}), \text { and } 22 \text { heavy } \\
(>10 \mathrm{~mm}) \text { storm events. }\end{array}$ & $\begin{array}{l}\text { Overall reductions in runoff } \\
\text { by the green roof were } \\
\text { found to be } 94.2 \% \text { during } \\
\text { light rainfall, } 89.5 \% \text { during } \\
\text { medium rainfall, and } 63.3 \% \\
\text { during heavy rainfall. }\end{array}$ & $\begin{array}{l}\text { The green roof and its design } \\
\text { has significant potential for } \\
\text { carbon sequestration. }\end{array}$ & [137] \\
\hline 5 & $\begin{array}{c}\text { Toronto, } \\
\text { Canada } \\
\text { Monitoring }\end{array}$ & 241 sq. meter & $\begin{array}{l}\text { A total of } 154 \text { individual } \\
\text { storm events were } \\
\text { considered between } \\
\text { May-November 2003, } \\
\text { June-November 2004, } \\
\text { and April-August 2005. } \\
\text { Monthly rainfall in the } \\
\text { selected period ranged from } \\
\text { 65-190 mm. }\end{array}$ & $\begin{array}{l}\text { The overall reduction of } \\
\text { runoff at monthly scale was } \\
\text { measured during the study } \\
\text { period. The reduction was } \\
\text { found to vary from } 34-95 \% \text {, } \\
\text { where the reduction was } \\
\text { more in summer months } \\
\text { and less in spring. }\end{array}$ & $\begin{array}{l}\text { The green roofs with vegetation } \\
\text { cover were able to sequester } \\
375 \text { g of carbon per square metre. } \\
\text { GThe green roof provides } \\
\text { opportunity to sequester carbon. }\end{array}$ & [138] \\
\hline
\end{tabular}


Table A1. Cont.

\begin{tabular}{|c|c|c|c|c|c|c|}
\hline Sl & $\begin{array}{l}\text { Location and } \\
\text { Analysis Type }\end{array}$ & $\begin{array}{c}\text { Size of } \\
\text { Study Area }\end{array}$ & Details of Weather/Climate & $\begin{array}{c}\text { Green roof } \\
\text { Details/Percentage } \\
\text { Improvement }\end{array}$ & Findings & Ref. \\
\hline 6 & $\begin{array}{l}\text { Vancouver } \\
\text { and Kelowna, } \\
\text { Canada, } \\
\text { and Shanghai, } \\
\text { China } \\
\text { Modeling } \\
\text { (SCS-CN) }\end{array}$ & $\begin{array}{l}\text { Vancouver: } \\
3500 \text { sq. meter; } \\
\text { Kelowna: } \\
3000 \text { sq. meter; } \\
\text { Shanghai: } \\
3700 \text { sq. meter. }\end{array}$ & $\begin{array}{l}\text { The annual rainfall of } \\
1224 \mathrm{~mm} \text { at Vancouver in } \\
2006,370.9 \mathrm{~mm} \text { at Kelowna } \\
\text { in } 1998 \text {, and } 1254.5 \mathrm{~mm} \text { at } \\
\text { Shanghai in } 2008 \text { were } \\
\text { considered for the study. }\end{array}$ & $\begin{array}{l}\text { The overall reduction of } \\
\text { runoff at the three cities } \\
\text { considered in the study are } \\
\text { as follows: Vancouver: } 29 \% \text {; } \\
\text { Kelowna: } 100 \% \text {; Shanghai: } \\
55 \% \text {. }\end{array}$ & $\begin{array}{l}\text { The model shows decreases in } \\
\text { daily actual evapotranspiration } \\
\text { as the antecedent dry period } \\
\text { increases. The presence of an } \\
\text { additional storage layer in the } \\
\text { green roof helps in reduction of } \\
\text { runoff and increases actual } \\
\text { evapotranspiration. }\end{array}$ & [123] \\
\hline 7 & $\begin{array}{l}\text { Northwest } \\
\text { and Central } \\
\text { Italy } \\
\text { Monitoring } \\
\text { and Modeling } \\
\text { (kinematic } \\
\text { wave model) }\end{array}$ & 72 sq. meter & $\begin{array}{l}\text { Monitoring was performed } \\
\text { over two phases, one before } \\
\text { deployment of the green } \\
\text { roof and another after the } \\
\text { deployment. In the first } \\
\text { phase, one storm event was } \\
\text { observed for } 3 \text { days from } \\
\text { 2-4 May } 2008 \text {, where the } \\
\text { daily rainfall was } 27.2 \mathrm{~mm} \text {, } \\
1.6 \mathrm{~mm} \text {, and } 43.2 \mathrm{~mm} \text {, } \\
\text { respectively. In second } \\
\text { phase, } 19 \text { rainfall events } \\
\text { were measured over one } \\
\text { year (mid-May 2007 to } \\
\text { mid-June 2008). }\end{array}$ & $\begin{array}{l}\text { A kinematic wave model } \\
\text { was developed to simulate } \\
\text { the expected runoff from an } \\
\text { impervious roof } \\
\text { corresponding to rainfall } \\
\text { received in the second } \\
\text { phase. The simulated runoff, } \\
\text { assuming an impervious } \\
\text { roof, was compared with } \\
\text { the observed runoff from } \\
\text { the green roof during the } \\
19 \text { storm events. The green } \\
\text { roof was found to reduce } \\
68 \% \text { of the average runoff. }\end{array}$ & $\begin{array}{l}\text { The performance of the green } \\
\text { roof is favourable also in the } \\
\text { Mediterranean regions, where } \\
\text { rainfall and the general climatic } \\
\text { conditions are less favourable } \\
\text { for vegetation to grow. }\end{array}$ & [139] \\
\hline 8 & $\begin{array}{l}\text { Sheffield, UK } \\
\text { Monitoring }\end{array}$ & 3 sq. meter & $\begin{array}{l}\text { A total of } 11 \text { individual } \\
\text { storm events were } \\
\text { monitored in } 2006 \text { and } 2007 . \\
\text { The total amount of rainfall } \\
\text { per event ranged from } \\
\quad 9.2-115.8 \mathrm{~mm} .\end{array}$ & $\begin{array}{l}\text { The performance of the } \\
\text { green roof in runoff } \\
\text { reduction was found to be } \\
10-35 \% \text { in the wet season } \\
\text { and } 65-100 \% \text { in the dry } \\
\text { season, with a mean of } 34 \% \\
\text { over the } 11 \text { storm events. }\end{array}$ & $\begin{array}{l}\text { Green roofs are able to provide } \\
\text { significant stormwater retention } \\
\text { in the UK climate. }\end{array}$ & [111] \\
\hline 9 & $\begin{array}{l}\text { Genoa, Italy } \\
\text { Monitoring } \\
\text { and Modeling } \\
\text { (SWMS-2D) }\end{array}$ & 350 sq. meter & $\begin{array}{l}\text { A total of } 19 \text { individual } \\
\text { storm events were } \\
\text { considered between May } \\
\text { 2007-August } 2008 . \\
\text { The rainfall depth during } \\
\text { the entire storm event } \\
\text { ranged from } 8-138.2 \mathrm{~mm} \text {. }\end{array}$ & $\begin{array}{c}\text { The reduction in runoff } \\
\text { during the storm events } \\
\text { varied from } 4.6-100 \% \text {, } \\
\text { with a mean reduction of } \\
89 \% \text {. }\end{array}$ & $\begin{array}{l}\text { Different hydraulic behaviours } \\
\text { between the growing medium } \\
\text { and the drainage layer were } \\
\text { observed. The hydrological } \\
\text { response of the green roof model } \\
\text { reproduces the discharge } \\
\text { hydrograph profile, volume, } \\
\text { and timing. }\end{array}$ & [127] \\
\hline 10 & $\begin{array}{l}\text { Michigan, } \\
\text { USA } \\
\text { Monitoring }\end{array}$ & 325.2 sq. meter & $\begin{array}{l}\text { Rainfall from } 21 \text { storm } \\
\text { events were measured from } \\
1 \text { April-30 September } 2008, \\
\text { at daily scale. The rainfall } \\
\text { ranged from } 4.06-74.68 \mathrm{~mm} \text {. }\end{array}$ & $\begin{array}{l}\text { Reduction in runoff during } \\
\text { those storm events ranged } \\
\text { from } 29.86-99.95 \% \text {, } \\
\text { with mean of } 68.25 \% \text {. } \\
\text { The overall reduction in } \\
\text { runoff for the entire } \\
\text { 6-month period was } 88.86 \% \text {. }\end{array}$ & $\begin{array}{l}\text { The green roof helped in } \\
\text { reducing peak discharge, } \\
\text { and also delaying the hydrologic } \\
\text { response. }\end{array}$ & [87] \\
\hline 11 & $\begin{array}{l}\text { Sheffield, UK } \\
\text { Monitoring }\end{array}$ & 3 sq. meter & $\begin{array}{l}\text { The daily rainfall data for } \\
29 \text { months were considered } \\
\text { from } 1 \text { January } 2007-31 \text { May } \\
2009 \text {. The monthly average } \\
\text { rainfall ranged from } 55 \mathrm{~mm} \\
\text { to } 91.9 \mathrm{~mm} \text { in the period, } \\
\text { with July being the driest } \\
\text { and December the wettest. }\end{array}$ & $\begin{array}{l}\text { The green roof reduced the } \\
\text { runoff by } 50.2 \% \text {, calculated } \\
\text { over the entire study period. } \\
\text { To understand the effect of } \\
\text { the green roof over } \\
\text { individual storm events, } \\
22 \text { significant rainfall events } \\
\text { were identified in the study } \\
\text { period, and an average of } \\
30 \% \text { reduction in runoff was } \\
\text { noted over those events. } \\
\text { The performance of the } \\
\text { green roof in runoff } \\
\text { reduction decreased with an } \\
\text { increase in rainfall depth, } \\
\text { with the amount of runoff } \\
\text { reduction varying from } \\
0-20 \text { mm. }\end{array}$ & $\begin{array}{l}\text { In winter, } \\
\text { the evapotranspiration and } \\
\text { retention values are reduced. } \\
\text { High levels of runoff and low } \\
\text { retention percentages can be } \\
\text { expected when considering long } \\
\text { return period events. }\end{array}$ & [77] \\
\hline
\end{tabular}


Table A1. Cont.

\begin{tabular}{|c|c|c|c|c|c|c|}
\hline Sl & $\begin{array}{l}\text { Location and } \\
\text { Analysis Type }\end{array}$ & $\begin{array}{c}\text { Size of } \\
\text { Study Area }\end{array}$ & Details of Weather/Climate & $\begin{array}{c}\text { Green roof } \\
\text { Details/Percentage } \\
\text { Improvement }\end{array}$ & Findings & Ref. \\
\hline 12 & $\begin{array}{l}\text { Wageningen, } \\
\text { Netherlands } \\
\text { Modeling } \\
\text { (SWAP) }\end{array}$ & NA & $\begin{array}{l}\text { Daily rainfall data were } \\
\text { considered for modeling for } \\
\text { the period 1954-1999. }\end{array}$ & $\begin{array}{l}\text { Green roof substrate depths, } \\
\text { ranging from } 5 \mathrm{~mm}-100 \mathrm{~mm} \text {, } \\
\text { were considered. Increases } \\
\text { in depth increased the } \\
\text { runoff volume retention. } \\
\text { The range of retention was } \\
\text { found to be } 55-75 \% \text {. }\end{array}$ & $\begin{array}{l}\text { Management cost and weight } \\
\text { are important variables for the } \\
\text { implementation of green roofs. }\end{array}$ & [126] \\
\hline 13 & $\begin{array}{l}\text { Wroclaw, } \\
\text { Poland } \\
\text { Monitoring; } \\
\text { Modeling } \\
\text { (SWMM) }\end{array}$ & $\begin{array}{l}2.88 \text { sq. meter, } \\
100 \mathrm{~mm} \text { thick }\end{array}$ & $\begin{array}{l}\text { A total of } 13 \text { individual } \\
\text { storm events from August } \\
\text { 2009-August } 2010 \text { were } \\
\text { considered in the study. } \\
\text { The maximum rainfall } \\
\text { intensity ranged from } \\
2.8-187.35 \mathrm{~mm} / \mathrm{h} \text {, while } \\
\text { rainfall duration ranged } \\
\text { from } 3.5-1572.5 \text { min. }\end{array}$ & $\begin{array}{l}\text { Based on the monitoring of } \\
\text { runoff from green roofs } \\
\text { during those storm events, } \\
\text { the runoff reduction ranged } \\
\text { from } 29.9-77.7 \% \text {, while the } \\
\text { SWMM simulation study of } \\
\text { green roofs showed an } \\
\text { reduction of runoff ranging } \\
\text { from } 54-99 \% \text {. }\end{array}$ & $\begin{array}{l}\text { The results of the green roof } \\
\text { model show a positive effect on } \\
\text { the reduction of volume, } \\
\text { peak intensity values, and on } \\
\text { the delay of the occurrence of } \\
\text { runoff. }\end{array}$ & [114] \\
\hline 14 & $\begin{array}{l}\text { Shropshire, } \\
\text { UK } \\
\text { Monitoring }\end{array}$ & 1 sq. meter & $\begin{array}{l}\text { A total of } 86 \text { rainy days data } \\
\text { between } 9 \text { December } \\
\text { 2009-12 June } 2010 \text { were } \\
\text { considered for the analysis. } \\
\text { The rainfall ranged from } \\
0.5-19.3 \mathrm{~mm} \text {, with a total } \\
\text { rainfall of } 236 \mathrm{~mm} .\end{array}$ & $\begin{array}{l}\text { Two different green roofs } \\
\text { were considered, one using } \\
\text { sedum decks with } 75 \mathrm{~mm} \\
\text { depth, and the other using } \\
\text { meadow decks with } 150 \mathrm{~mm} \\
\text { depth. The overall } \\
\text { performance of those green } \\
\text { roofs in runoff reduction } \\
\text { over the } 86 \text { days was } 40 \% \\
\text { for sedum and } 48 \% \text { for } \\
\text { meadow decks, respectively. }\end{array}$ & $\begin{array}{l}\text { The water-retention } \\
\text { performance of green roofs } \\
\text { varies seasonally, due to } \\
\text { differences in rainfall patterns. }\end{array}$ & [100] \\
\hline 15 & $\begin{array}{l}\text { Manchester, } \\
\text { UK } \\
\text { Monitoring }\end{array}$ & 900 sq. meter & $\begin{array}{c}\text { A total of } 69 \text { rainfall events } \\
\text { were considered for the } \\
\text { analysis. The annual } \\
\text { average rainfall was } \\
828.8 \mathrm{~mm} \text {, } \\
\text { with October-December as } \\
\text { the wettest period } \\
\text { (80.7-92.5 mm rainfall), } \\
\text { while February -May is the } \\
\text { driest (51.4-61.2 mm } \\
\text { rainfall). }\end{array}$ & $\begin{array}{l}\text { The overall performance of } \\
\text { intensive green roofs of } \\
500 \mathrm{~mm} \text { depth in runoff } \\
\text { reduction was found to be } \\
\text { around } 50 \% \text { in winter } \\
\text { months and close to } 100 \% \\
\text { during dry months, with an } \\
\text { overall average of } 65.7 \% \\
\text { over the } 69 \text { storm events. }\end{array}$ & $\begin{array}{l}\text { The highest retention of rainfall } \\
\text { was achieved in summer. } \\
\text { The age of the green roof is not } \\
\text { an issue and does not affect the } \\
\text { effectiveness of green roofs. }\end{array}$ & [75] \\
\hline 16 & $\begin{array}{l}\text { Northwest } \\
\text { Scotland; } \\
\text { Sheffield UK; } \\
\text { Cornwall UK; } \\
\text { East Midlands } \\
\text { UK } \\
\text { Modeling } \\
\text { (CHFM) }\end{array}$ & NA & $\begin{array}{l}\text { This study considered the } \\
\text { effectiveness of green roofs } \\
\text { in runoff reduction at four } \\
\text { locations: NW Scotland, } \\
\text { Sheffield, Cornwall, } \\
\text { and East Midlands, where } \\
\text { the annual average rainfall } \\
\text { are } 2708 \mathrm{~mm}, 838 \mathrm{~mm}, \\
1365 \mathrm{~mm} \text {, and } 496 \mathrm{~mm}, \\
\text { respectively. }\end{array}$ & $\begin{array}{l}\text { Based on the CHFM } \\
\text { simulation study, the overall } \\
\text { runoff reduction due to } \\
\text { green roofs in the four areas } \\
\text { are as follows: NW Scotland: } \\
\text { 19\%; Sheffield: } 40 \% \text {; } \\
\text { Cornwall: } 33 \% \text {; East } \\
\text { Midlands: } 59 \% \text {. }\end{array}$ & $\begin{array}{l}\text { The green roof's capacity for } \\
\text { retaining rainfall is dependent } \\
\text { upon evapotranspiration for the } \\
\text { period prior to a storm event. }\end{array}$ & [119] \\
\hline 17 & $\begin{array}{l}\text { Edwardsville, } \\
\text { USA } \\
\text { Monitoring }\end{array}$ & 0.363 sq. meter & $\begin{array}{l}\text { Rainfall data were collected } \\
\text { in two stages, first from } \\
\text { September 2005-March } \\
\text { 2007, and from April } \\
\text { 2007-June 2008. The total } \\
\text { rainfall during first stage } \\
\text { was } 1244.8 \mathrm{~mm} \text {, with } \\
\text { monthly precipitation } \\
\text { ranging from 5-120 mm } \\
\text { over } 101 \text { individual storm } \\
\text { events, while during the } \\
\text { second stage, the total } \\
\text { rainfall was } 1397.7 \text { mm, } \\
\text { with monthly precipitation } \\
\text { from } 20-230 \text { mm over } \\
74 \text { individual storm events. }\end{array}$ & $\begin{array}{l}\text { The overall reduction in } \\
\text { runoff due to the green roof } \\
\text { in the first and second stage } \\
\text { for extensive green roofs } \\
\text { was } 38.6 \% \text { and } 42.9 \% \text {, } \\
\text { respectively, while that for } \\
\text { intensive green roofs was } \\
50.8 \% \text { and } 54.3 \% \text {, } \\
\text { respectively. }\end{array}$ & $\begin{array}{l}\text { The design of a green roof, } \\
\text { for example, the type of growth } \\
\text { media, its depth, and the } \\
\text { presence or absence of a } \\
\text { drainage layer, plays a vital role } \\
\text { in determining the performance. }\end{array}$ & [140] \\
\hline
\end{tabular}


Table A1. Cont.

\begin{tabular}{|c|c|c|c|c|c|c|}
\hline Sl & $\begin{array}{l}\text { Location and } \\
\text { Analysis Type }\end{array}$ & $\begin{array}{c}\text { Size of } \\
\text { Study Area }\end{array}$ & Details of Weather/Climate & $\begin{array}{c}\text { Green roof } \\
\text { Details/Percentage } \\
\text { Improvement }\end{array}$ & Findings & Ref. \\
\hline 18 & $\begin{array}{l}\text { Auckland, } \\
\text { New Zealand } \\
\text { Monitoring }\end{array}$ & 217 sq. meter & $\begin{array}{l}\text { Daily rainfall was collected } \\
\text { for } 2008 \text {. The annual } \\
\text { average rainfall was } \\
\text { approximately } 1200 \mathrm{~mm} \text {, } \\
\text { which is evenly distributed } \\
\text { throughout the year, where } \\
\text { average wet days is } 137 .\end{array}$ & $\begin{array}{c}\text { Median values of runoff } \\
\text { retention by green roof } \\
\text { varies from } 81-85 \% \text { per } \\
\text { event in spring and } 83-92 \% \\
\text { in summer, which decreased } \\
\text { to } 45-75 \% \text { in autumn and } \\
66 \% \text { in winter. }\end{array}$ & $\begin{array}{l}\text { Maintaining conditions for } \\
\text { runoff lag time, peak flow, } \\
\text { and duration of flow were } \\
\text { tested. The peak flow from } \\
\text { drainage was less flashy and } \\
\text { tended to show variations in } \\
\text { runoff compared to asphalt } \\
\text { surfaces, which showed spikes } \\
\text { in rainfall runoff intensity. }\end{array}$ & [141] \\
\hline 19 & $\begin{array}{l}\text { New York, } \\
\text { USA } \\
\text { Monitoring }\end{array}$ & 310 sq. meter & $\begin{array}{l}\text { A total of } 243 \text { storm event } \\
\text { data at daily scale were } \\
\text { collected from June } 2011 \text { to } \\
\text { June } 2012 . \text { The rainfall } \\
\text { depth varied from } \\
0.25-180 \mathrm{~mm} .\end{array}$ & $\begin{array}{l}\text { Three green roofs were } \\
\text { deployed and the } \\
\text { percentage reductions in } \\
\text { runoff were measured. } \\
\text { The overall reductions in } \\
\text { runoff during the study } \\
\text { period were found to be } 36 \% \\
\text { for extensive green roof of } \\
32 \text { mm depth made of } \\
\text { vegetated mat, } 47 \% \text { for } \\
\text { intensive green roof of } \\
100 \text { mm made of sedum mix, } \\
\text { and } 61 \% \text { for intensive green } \\
\text { roof of } 100 \text { mm made of } \\
\text { sedum mix with modular } \\
\text { trays. }\end{array}$ & $\begin{array}{l}\text { Retention rates are higher for } \\
\text { rainfall event-based approaches. } \\
\text { In case of large rainfall events, } \\
\text { representation of a series of } \\
\text { smaller 'daily' events when } \\
\text { using a daily record is the more } \\
\text { accurate approach. }\end{array}$ & {$[71]$} \\
\hline 20 & $\begin{array}{l}\text { Manhattan, } \\
\text { New York } \\
\text { Modeling } \\
\text { (HYDRUS-1D) }\end{array}$ & $\begin{array}{l}310 \text { sq. meter, } \\
99 \text { sq. meter } \\
\text { and } 0.09 \text { sq. } \\
\text { meter }\end{array}$ & $\begin{array}{l}\text { This study considered } \\
3 \text { different green roofs and } \\
\text { measured rainfall data } \\
\text { corresponding to individual } \\
\text { storm events at those } \\
\text { locations. The first location } \\
\text { had } 63 \text { events (small } \\
(<20 \mathrm{~mm}): 41 \text {; medium } \\
(20-40 \mathrm{~mm}): 13 \text {; large } \\
\text { (>40 mm): } 9) \text {. The second } \\
\text { location had } 79 \text { events } \\
\text { (small: } 70 ; \text { medium: } 5 \text {; large: } \\
\text { 4), and the third location } \\
\text { had } 6 \text { events (small: } 3 \text {; } \\
\text { medium: } 2 \text {; large: } 1) \text {. }\end{array}$ & $\begin{array}{l}\text { The overall reduction in } \\
\text { runoff for all three green } \\
\text { roofs was found to be } 85 \% \\
\text { for small rainfall events, } \\
48 \% \text { for medium events, } \\
\text { and } 32 \% \text { for large events. }\end{array}$ & $\begin{array}{l}\text { Rainfall depth and event } \\
\text { duration have the maximum } \\
\text { influence on overall green roof } \\
\text { rainfall retention. Rainfall } \\
\text { intensity and its relation to the } \\
\text { antecedent dry weather period } \\
\text { (ADWP) has little influence on } \\
\text { the aggregate performance of } \\
\text { the green roof systems. } \\
\text { The green roof retention and } \\
\text { peak reduction generally } \\
\text { decrease as rainfall volume } \\
\text { increases. }\end{array}$ & [120] \\
\hline 21 & $\begin{array}{l}\text { Soacha, } \\
\text { Colombia } \\
\text { Modeling } \\
\text { (SWMM) }\end{array}$ & $\sim 35$ sq. meter & $\begin{array}{l}\text { A total of } 8 \text { storm events } \\
\text { recorded from March-April } \\
2012 \text { were analyzed. } \\
\text { The rainfall intensity during } \\
\text { those events varied from } \\
\quad 0.24-15.27 \mathrm{~mm} / \mathrm{h} .\end{array}$ & $\begin{array}{l}\text { The SWMM model } \\
\text { predicted a runoff reduction } \\
\text { from } 5.7-92.2 \% \text {, with an } \\
\text { average of } 51.4 \% \text { runoff } \\
\text { reduction due to the green } \\
\text { roof. }\end{array}$ & $\begin{array}{l}\text { Green roofs play an important } \\
\text { role in hydrologic attenuation, } \\
\text { depicting a strong relationship } \\
\text { between plant type used and the } \\
\text { green roof's hydrologic response } \\
\text { to weather events. }\end{array}$ & [115] \\
\hline 22 & $\begin{array}{l}\text { Adelaide, } \\
\text { Australia } \\
\text { Monitoring }\end{array}$ & 1.8 sq. meter & $\begin{array}{l}\text { The study considered } \\
226 \text { storm events with a total } \\
\text { rainfall of } 967.8 \mathrm{~mm} \text {, where } \\
\text { rainfall intensity varied } \\
\text { from } 0.31-7.16 \mathrm{~mm} / \mathrm{h} .\end{array}$ & $\begin{array}{l}\text { Reduction in runoff for } \\
\text { extensive green roofs over } \\
\text { the storm events ranged } \\
\text { from } 66.38-81.66 \% \text {, while } \\
\text { that for intensive green } \\
\text { roofs was } 85.05-92.19 \% \text {. }\end{array}$ & $\begin{array}{l}\text { Extensive as well as intensive } \\
\text { green roofs can retain significant } \\
\text { volumes of stormwater runoff. } \\
\text { An average runoff delay time of } \\
\text { almost } 3 \mathrm{~h} \text { was observed in } \\
\text { extensive roofs and the } \\
\text { corresponding delay time was } \\
\text { up to } 17 \mathrm{~h} \text { in intensive roofs, } \\
\text { which both indicate that green } \\
\text { roofs can effectively attenuate } \\
\text { peak runoff flows. }\end{array}$ & [107] \\
\hline
\end{tabular}


Table A1. Cont.

\begin{tabular}{|c|c|c|c|c|c|c|}
\hline Sl & $\begin{array}{l}\text { Location and } \\
\text { Analysis Type }\end{array}$ & $\begin{array}{c}\text { Size of } \\
\text { Study Area }\end{array}$ & Details of Weather/Climate & $\begin{array}{c}\text { Green roof } \\
\text { Details/Percentage } \\
\text { Improvement }\end{array}$ & Findings & Ref. \\
\hline 23 & $\begin{array}{l}\text { Hong Kong } \\
\text { Monitoring }\end{array}$ & 1.1 sq. meter & $\begin{array}{l}\text { A total of } 63 \text { individual } \\
\text { storm events were } \\
\text { considered in the study } \\
\text { from July } 2012-\text { April } 2013 \text {. } \\
\text { A total of } 19 \text { events had } \\
\text { rainfall }<2 \mathrm{~mm} \text {; } 18 \text { events } \\
\text { had rainfall between } \\
2-10 \mathrm{~mm} \text {, while } 26 \text { events } \\
\text { had }>10 \mathrm{~mm} \text { rainfall. }\end{array}$ & $\begin{array}{l}\text { Four different green roofs } \\
\text { (two depths: } 40 \mathrm{~mm} \text { and } \\
80 \mathrm{~mm} \text {, and two substrate } \\
\text { types: sandy loam and } \\
\text { hydrophilic mineral wool) } \\
\text { were considered in the } \\
\text { study. The overall mean } \\
\text { reduction of runoff for each } \\
\text { type of green roof over the } \\
63 \text { storm events was } 38.9 \% \\
\text { (40 mm sandy loam), } 40 \% \\
(40 \mathrm{~mm} \text { wool), } 45.3 \% \\
(80 \mathrm{~mm} \text { sandy loam), } \\
\text { and } 44.3 \% \text { ( } 80 \mathrm{~mm} \text { wool). }\end{array}$ & $\begin{array}{l}\text { Sufficient peak mitigation can be } \\
\text { achieved even for extensive } \\
\text { green roofs with thin } 40-\mathrm{mm} \\
\text { substrates. Thus, lightweight } \\
\text { green roof design can be } \\
\text { considered for buildings with } \\
\text { loading concerns. }\end{array}$ & {$[142]$} \\
\hline 24 & $\begin{array}{l}\text { Ma'anshan, } \\
\text { China } \\
\text { Modeling } \\
\text { (SUSTAIN) }\end{array}$ & $\begin{array}{l}32585 \text { sq. } \\
\text { meter }\end{array}$ & $\begin{array}{l}\text { Daily rainfall was } \\
\text { considered for simulation } \\
\text { modeling, where the annual } \\
\text { average rainfall is } 1100 \mathrm{~mm}, \\
48 \% \text { of which occurs during } \\
\text { June-August. }\end{array}$ & $\begin{array}{l}\text { The hypothetical } \\
\text { deployment of green roofs } \\
\text { in the catchment would } \\
\text { result in overall runoff } \\
\text { reduction of } 36 \% .\end{array}$ & $\begin{array}{l}\text { The green roofs were an optimal } \\
\text { option for achieving the } \\
\text { optimum runoff reduction goal. }\end{array}$ & [125] \\
\hline 25 & $\begin{array}{l}\text { Leeds, UK } \\
\text { Monitoring }\end{array}$ & 830 sq. meter & $\begin{array}{l}\text { A total of } 30 \text { individual } \\
\text { storm events between June } \\
2012 \text { and December } \\
2013 \text { were recorded. } \\
\text { The rainfall ranged from } \\
5-84 \mathrm{~mm} \text { with a mean of } \\
10.07 \mathrm{~mm} \text {. }\end{array}$ & $\begin{array}{l}\text { Reduction in runoff from } \\
\text { the green roof with } 30-\mathrm{mm} \\
\text { deep sedum carpet ranged } \\
\text { from } 3.57-100 \% \text {, with mean } \\
\text { of } 66.21 \% \text { over the } 30 \text { storm } \\
\text { events. }\end{array}$ & $\begin{array}{l}\text { The green roof was able to } \\
\text { detain rainfall and attenuate } \\
\text { peak runoff flows, } \\
\text { when compared to a } \\
\text { conventional roof. }\end{array}$ & {$[143]$} \\
\hline 26 & $\begin{array}{l}\text { Seoul, Korea } \\
\text { Modeling } \\
\text { (SWMM) }\end{array}$ & NA & $\begin{array}{l}\text { The study considered a } \\
\text { single storm event, which } \\
\text { occurred over } 90 \text { min in } \\
2011 .\end{array}$ & $\begin{array}{l}\text { The SWMM model } \\
\text { simulation was run for } 30 \mathrm{~h} \\
\text { and the percentages of } \\
\text { runoff reduction for two } \\
\text { scenarios were estimated. } \\
\text { In the first scenario, } 51 \% \text { of } \\
\text { the roof area was assumed } \\
\text { to be green roof, while in the } \\
\text { second scenario, entire roof } \\
\text { was converted to green roof. } \\
\text { Reduction in runoff } \\
\text { increased from } 14.7 \% \text { in the } \\
\text { first scenario to } 25.6 \% \text { in the } \\
\text { second scenario. }\end{array}$ & $\begin{array}{l}\text { Stormwater runoff reduction in } \\
\text { urban areas is achieved using } \\
\text { green roofs. }\end{array}$ & [116] \\
\hline 27 & $\begin{array}{l}\text { Beijing, China } \\
\text { Monitoring }\end{array}$ & 120 sq. meter & $\begin{array}{l}\text { A total of } 13 \text { individual } \\
\text { storm events from } \\
\text { April-July } 2012 \text { were } \\
\text { considered in the study. } \\
\text { The rainfall ranged from } \\
\text { 1.8-190.4 mm, with rainfall } \\
\text { duration varying from } \\
\text { 20-2715 min. }\end{array}$ & $\begin{array}{l}\text { Percentage reduction in } \\
\text { runoff due to green roofs } \\
\text { over the storm events varied } \\
\text { from } 17.1-100 \% \text {, where } \\
100 \% \text { attenuation occurred } \\
\text { for storms with }<10 \mathrm{~mm} \\
\text { rainfall, and the } \\
\text { performance decreased with } \\
\text { an increase in rainfall. }\end{array}$ & $\begin{array}{l}\text { The medium layer or a high } \\
\text { initial soil moisture can decrease } \\
\text { the rainwater retention capacity } \\
\text { of a green roof by generating } \\
\text { more runoff. }\end{array}$ & [73] \\
\hline 28 & $\begin{array}{l}\text { Seoul, Korea } \\
\text { Monitoring }\end{array}$ & 1 sq. meter & $\begin{array}{l}\text { A total of } 7 \text { rainfall events in } \\
2003 \text { was considered, where } \\
\text { the rainfall duration varied } \\
\text { from } 2-17 \mathrm{~h} \text {, and the total } \\
\text { rainfall ranged from } \\
\quad 3.5-115 \mathrm{~mm} .\end{array}$ & $\begin{array}{l}\text { Two intensive green roofs of } \\
\text { depth } 150 \mathrm{~mm} \text { and } 200 \mathrm{~mm} \\
\text { were considered. } \\
\text { The performance of the } \\
\text { green roofs in the reduction } \\
\text { of runoff corresponding to } \\
\text { the } 7 \text { storm events ranged } \\
\text { from } 13.8-34.4 \% \text { for } 150 \mathrm{~mm} \\
\text { green roofs and } 42.8-60.8 \% \\
\text { for } 200 \mathrm{~mm} \text { green roofs. }\end{array}$ & $\begin{array}{l}\text { The extensive green roof system } \\
\text { was analyzed, and it was found } \\
\text { that it achieved a } 13.8-60.8 \% \\
\text { reduction in runoff for the total } \\
\text { rainfall. }\end{array}$ & $[108])$ \\
\hline
\end{tabular}


Table A1. Cont.

\begin{tabular}{|c|c|c|c|c|c|c|}
\hline Sl & $\begin{array}{l}\text { Location and } \\
\text { Analysis Type }\end{array}$ & $\begin{array}{c}\text { Size of } \\
\text { Study Area }\end{array}$ & Details of Weather/Climate & $\begin{array}{c}\text { Green roof } \\
\text { Details/Percentage } \\
\text { Improvement }\end{array}$ & Findings & Ref. \\
\hline 29 & $\begin{array}{l}\text { Victoria, } \\
\text { Australia } \\
\text { Modeling } \\
\text { (MOUSE) }\end{array}$ & NA & $\begin{array}{l}\text { The study considered a } 24 \mathrm{~h} \\
\text { rainfall event corresponding } \\
\text { to a } 10 \text {-year return period., } \\
\text { where the rainfall intensity } \\
\text { ranged from } 2.93-26 \mathrm{~mm} / \mathrm{h} \text {. }\end{array}$ & $\begin{array}{l}\text { The overall reduction in } \\
\text { runoff for the } 24 \mathrm{~h} \text { event } \\
\text { ranged from } 9.77-11.88 \% \text {. }\end{array}$ & $\begin{array}{l}\text { Eco-roof technology has been } \\
\text { effective for mitigating flood } \\
\text { extents since it is capable of } \\
\text { retaining rainwater and } \\
\text { reducing rainfall-runoff. }\end{array}$ & [122] \\
\hline 30 & $\begin{array}{l}\text { Seveso basin, } \\
\text { Italy } \\
\text { Modeling } \\
\text { (SWMM) }\end{array}$ & NA & $\begin{array}{l}\text { The average hourly rainfall } \\
\text { for every month was } \\
\text { obtained based on observed } \\
\text { rainfall data from January } \\
2010 \text { to March } 2015 . \\
\text { The monthly average } \\
\text { rainfall was lowest in March } \\
\text { (60 mm/month) and highest } \\
\text { in November } \\
\text { ( } 210 \mathrm{~mm} / \text { month). }\end{array}$ & $\begin{array}{l}\text { Based on the SWMM } \\
\text { simulation study, } \\
\text { the reduction of runoff due } \\
\text { to the green roof varies from } \\
2.8-35.3 \% \text {, depending on } \\
\text { rainfall in each month. }\end{array}$ & $\begin{array}{l}\text { To understand green roof } \\
\text { susceptibility, the initial } \\
\text { conditions are significant in } \\
\text { terms of the volumetric water } \\
\text { content of the substrate. } \\
\text { The use of green roofs at } 5 \% \\
\text { coverage of all roofs reduces the } \\
\text { peak flow by between } 1.3 \text { and } \\
2 \% \text {. Whereas, with a } 100 \% \\
\text { greening scenario, } \\
\text { the percentage of peak flow } \\
\text { reduction equal to } 30 \% \text {, appears } \\
\text { to be excellent. }\end{array}$ & [117] \\
\hline 31 & $\begin{array}{l}\text { Singapore } \\
\text { Modeling } \\
\text { (Sobek) }\end{array}$ & NA & $\begin{array}{l}\text { Rainfall was measured from } \\
\text { August 2009-December } \\
\text { 2011, with rainfall ranging } \\
\text { from } 0.7-260.7 \mathrm{~mm} \text {. }\end{array}$ & $\begin{array}{c}\text { The simulation study was } \\
\text { performed by assuming } \\
25 \%, 50 \% \text {, and } 100 \% \\
\text { conversion of roofs to green } \\
\text { roofs. The percentage } \\
\text { reduction of runoff, } \\
\text { corresponding to the three } \\
\text { hypothetical cases in the } \\
\text { catchmen, } \mathrm{t} \text { are } 0.6 \%, 1.2 \% \text {, } \\
\text { and } 2.4 \% \text {, respectively. }\end{array}$ & $\begin{array}{l}\text { The catchment-scale } \\
\text { implementation of green roofs } \\
\text { had a positive effect for the } \\
\text { reduction of peak discharges at } \\
\text { the Marina Reservoir, although } \\
\text { the peak reduction is lower } \\
\text { compared to that in temperate } \\
\text { climates. }\end{array}$ & [124] \\
\hline 32 & $\begin{array}{l}\text { Warsaw, } \\
\text { Poland } \\
\text { Monitoring }\end{array}$ & 1.44 sq. meter & $\begin{array}{l}\text { The rainfall values of } 64.1, \\
92.4 \text {, and } 138 \mathrm{dm}^{3} / \mathrm{s} / \mathrm{ha}, \\
\text { corresponding to } 1-, 3-, \\
\text { and } 10 \text {-year return periods, } \\
\text { respectively, } \\
\text { were considered for the } \\
\text { lab-based test, where the } \\
\text { rainfall duration was chosen } \\
\text { to be } 20 \text { min. }\end{array}$ & $\begin{array}{l}\text { The reduction in runoff was } \\
\text { found to be } 48.3 \% \text {, } \\
\text { corresponding to rainfall } \\
\text { with a } 10 \text {-year return period, } \\
70 \% \text { for a } 3 \text {-year return } \\
\text { period rainfall, and } 84 \% \text { for } \\
\text { rainfall of a 1-year return } \\
\text { period. }\end{array}$ & $\begin{array}{l}\text { There is a reduction of } \\
\text { discharged rainwater from } \\
\text { extensive green roofs. } \\
\text { The thickness of the substrate } \\
\text { enables the retention of the } \\
\text { precipitation. }\end{array}$ & {$[144]$} \\
\hline 33 & $\begin{array}{l}\text { Seoul, Korea } \\
\text { Monitoring }\end{array}$ & 285 sq. meter & $\begin{array}{l}\text { A single storm event was } \\
\text { considered on } 3 \text { September } \\
\text { 2014, where the maximum } \\
\text { intensity of rainfall was } \\
60 \mathrm{~mm} / \mathrm{hr} .\end{array}$ & $\begin{array}{l}\text { A } 200-\mathrm{mm} \text { depth intensive } \\
\text { green roof was used to } \\
\text { measure the reduction in } \\
\text { runoff for the storm event, } \\
\text { which was found to be } 68 \% \text {. }\end{array}$ & $\begin{array}{c}\text { Green and blue roofs can handle } \\
\text { big storm events more } \\
\text { effectively as compared to blue } \\
\text { roofs. }\end{array}$ & [145] \\
\hline 34 & $\begin{array}{l}\text { Lisbon, } \\
\text { Portugal } \\
\text { Monitoring }\end{array}$ & 2.5 sq. meter & $\begin{array}{l}\text { Rainfall was measured from } \\
\text { September } 2014-\text { February } \\
\text { 2015. The average rainfall } \\
\text { was } 0.4 \mathrm{~mm} / \mathrm{h} .\end{array}$ & $\begin{array}{l}\text { Three types of green roof } \\
\text { were considered in the } \\
\text { study. The overall average } \\
\text { reduction of runoff was } \\
\text { found to be: } 82 \% \text { for a mix } \\
\text { of plants and moss, } 73.2 \% \\
\text { for shrubs, and } 71.1 \% \text { for } \\
\text { grass. }\end{array}$ & $\begin{array}{l}\text { For rainfall runoff reduction, } \\
\text { the best results were obtained } \\
\text { for the rainfall class of short } \\
\text { durations, regardless of } \\
\text { intensity, and the worst for the } \\
\text { class of high maximum } \\
\text { intensities and long durations. }\end{array}$ & [112] \\
\hline 35 & $\begin{array}{l}\text { Hypothetical } \\
\text { study area } \\
\text { Modeling } \\
\text { (SWMM) }\end{array}$ & 390.2 sq. meter & $\begin{array}{l}\text { The study considered } \\
10 \text { storm events with rainfall } \\
\text { depths ranging from } \\
0.3-11.3 \mathrm{~mm} \text { and durations } \\
\text { varying from } 3-30 \mathrm{~h} .\end{array}$ & $\begin{array}{l}\text { Based on the SWMM } \\
\text { simulation study, } \\
\text { the decrease in runoff from } \\
\text { a green roof of depth } \\
12.7 \mathrm{~mm} \text { was found to be } \\
0-28 \% \text {, depending on the } \\
\text { rainfall intensity. Increases } \\
\text { in rainfall intensity reduced } \\
\text { the performance of the } \\
\text { green roof in runoff } \\
\text { reduction. }\end{array}$ & $\begin{array}{l}\text { The study found that installing } \\
\text { stormwater control measures in } \\
\text { downstream catchments is more } \\
\text { efficient for reducing peak flow } \\
\text { and runoff volume, compared to } \\
\text { installing stormwater controls in } \\
\text { upstream catchments. }\end{array}$ & [118] \\
\hline
\end{tabular}


Table A1. Cont.

\begin{tabular}{|c|c|c|c|c|c|c|}
\hline Sl & $\begin{array}{l}\text { Location and } \\
\text { Analysis Type }\end{array}$ & $\begin{array}{c}\text { Size of } \\
\text { Study Area }\end{array}$ & Details of Weather/Climate & $\begin{array}{c}\text { Green roof } \\
\text { Details/Percentage } \\
\text { Improvement }\end{array}$ & Findings & Ref. \\
\hline 36 & $\begin{array}{l}\text { Victoria, } \\
\text { Australia } \\
\text { Modeling } \\
\text { (SCS-CN) }\end{array}$ & 844 sq. meter & $\begin{array}{l}\text { Based on historical rainfall } \\
\text { data, a } 24 \mathrm{~h} \text { hypothetical } \\
\text { rainfall event was generated } \\
\text { for the simulation study. }\end{array}$ & $\begin{array}{l}\text { The simulation model } \\
\text { predicted a reduction of } \\
66.6 \% \text { runoff due to the } \\
150-\mathrm{mm} \text { thick green roof. }\end{array}$ & $\begin{array}{l}\text { The green roof model generated } \\
\text { varying degrees of mitigation } \\
\text { for the urban flash floods } \\
\text { induced by storms. }\end{array}$ & {$[11]$} \\
\hline 37 & $\begin{array}{l}\text { Athens, } \\
\text { Greece } \\
\text { Monitoring }\end{array}$ & 69.3 sq. meter & $\begin{array}{l}\text { Rainfall was observed from } \\
15 \text { January } 2015 \text { for one year. } \\
\text { The individual storm events } \\
\text { in the period ranged from } \\
20-1670 \text { min, with overall } \\
\text { rainfall depth ranging from } \\
0.6-45.4 \mathrm{~mm} \text {, and the } \\
\text { rainfall intensity varying } \\
\text { from } 0.01-1.4 \mathrm{~mm} / \mathrm{min} .\end{array}$ & $\begin{array}{l}\text { The performance of five } \\
\text { types of green roofs were } \\
\text { explored in the study. } \\
\text { The overall performance in } \\
\text { runoff reduction were found } \\
\text { as: Origanum onites with } \\
80 \text { mm depth: } 63.6 \% \text {; sedum } \\
\text { with } 160 \mathrm{~mm} \text { depth: } 60.3 \% \text {; } \\
\text { sedum with } 80 \mathrm{~mm} \text { depth: } \\
50.8 \% \text {; festuca with } 160 \mathrm{~mm} \\
\text { depth: } 68.8 \% \text {; and festuca } \\
\text { with } 80 \mathrm{~mm} \text { depth: } 54.9 \% \text {. }\end{array}$ & $\begin{array}{l}\text { The runoff reduction was more } \\
\text { when the substrate level was } \\
\text { deeper than } 16 \mathrm{~cm} \text {, which was } \\
\text { combined with vegetation cover, } \\
\text { or when the initial moisture } \\
\text { content in the substrate was low } \\
\text { or the rainfall depth was small. }\end{array}$ & {$[74]$} \\
\hline 38 & $\begin{array}{l}\text { Munich, } \\
\text { Germany } \\
\text { Modeling } \\
\text { (MIKE-SHE) }\end{array}$ & $\begin{array}{l}5400-27000 \text { sq. } \\
\text { meter }\end{array}$ & $\begin{array}{l}\text { A 2-year return period } \\
\text { rainfall at hourly time scale } \\
\text { was considered for the } \\
\text { simulation study. }\end{array}$ & $\begin{array}{l}\text { Assuming } 20 \% \text { of the roof } \\
\text { area was converted to green } \\
\text { roof, a runoff reduction of } \\
1.4 \% \text { was found in the } \\
\text { catchment, while } 100 \% \\
\text { conversion in green roof } \\
\text { increased the performance } \\
\text { to } 14.8 \% \text {. }\end{array}$ & $\begin{array}{l}\text { The performance of green } \\
\text { infrastructure effectiveness } \\
\text { remains low under heavy rain } \\
\text { events, unless a significantly } \\
\text { large proportion of the area is } \\
\text { greened, which could provide } \\
\text { sufficient water storage } \\
\text { capacities. }\end{array}$ & [47] \\
\hline
\end{tabular}

\section{Artificial rainfall was} generated with $0.33 \mathrm{~mm} / \mathrm{min}$ intensity. A total of 5, 10, 25, 50, 100, and $250 \mathrm{~mm} /$ day rainfall

$39 \begin{gathered}\text { Shanghai, } \\ \text { China } \\ \text { Monitoring }\end{gathered} \quad 7.767$ sq. meter
representing light, moderate, large, rainstorm, large rainstorm, and extraordinary large rainfall events were generated by spraying the water for a duration of 15,30 , $75,150,300$, and $750 \mathrm{~min}$, respectively.

The reduction in runoff from the green roof was highest for light rainfall, and gradually decreased as the rainfall depth increased.

The range of runoff reduction decreased from $83 \%$ to $15 \%$.
The type of plant species significantly affected the hydrological performance and the rate of runoff reduction from extensive green roofs.
Rainfall data at daily scale was collected from 1 February 2014-31 January 2015. The total rainfall was $807.6 \mathrm{~mm}$, with $70 \%$ rainfall occurring in Nov-April.

\section{Portland, USA \\ Monitoring}

1200 sq. meter

Seoul, Korea Monitoring

663 sq. meter
Hourly rainfall was measured from June-November 2017 and rainfall with more than $60 \mathrm{~mm} / \mathrm{h}$ was considered in the analysis.
Two green roofs were considered for the study with varying depths. The first one had a $75 \mathrm{~mm}$ depth and reduced runoff

by the amount of $17.7-48.8 \%$, while the second green roof had a $125 \mathrm{~mm}$ depth and the reduction of runoff was $20.2-96.6 \%$.

The effectiveness of the $30 \mathrm{~mm}$ depth was found to reduce runoff by $10-60 \%$, depending on the intensity and duration of the rainfall. extensive green roof of

The long-term vegetated systems on green roofs will tend to offer higher moisture removal due to evapotranspiration. Additionally, the large-pored substrate has a lower maximum moisture-holding capacity.

The rainwater is first stored on the green roof and then infiltrates to the ground surface. In this way, a peak flow delay is achieved during storm events. As a result, there is reduction in the occurrence of flash flooding in highly urbanized areas.

The performance of the green roof in runoff reduction was measured for two types of vegetation: sedum and Artificial rainfall was where the rainfall intensity was $28 \mathrm{~mm} / \mathrm{h}$ and the total rainfall was $9.3 \mathrm{~mm}$.
The evapotranspiration rates are conditions. The contribution of the plant's transpiration component is important in 'cool' and 'humid' conditions. high in 'warm' and 'hot'
Stachys. Runoff reduction for

Sedum was $17.1 \%$, and for Stachys was $13.1 \%$. 
Table A1. Cont.

\begin{tabular}{|c|c|c|c|c|c|c|}
\hline S1 & $\begin{array}{l}\text { Location and } \\
\text { Analysis Type }\end{array}$ & $\begin{array}{c}\text { Size of } \\
\text { Study Area }\end{array}$ & Details of Weather/Climate & $\begin{array}{c}\text { Green roof } \\
\text { Details/Percentage } \\
\text { Improvement }\end{array}$ & Findings & Ref. \\
\hline 43 & $\begin{array}{l}\text { Gansu } \\
\text { province, } \\
\text { China } \\
\text { Monitoring }\end{array}$ & 1 sq. meter & $\begin{array}{l}\text { A total of } 66 \text { rainfall events } \\
\text { were considered and } \\
\text { subdivided into low- and } \\
\text { high-intensity rainfalls. } \\
\text { The subdivision was based } \\
\text { on the medium rainfall } \\
\text { intensity equal to } \\
0.38 \mathrm{~mm} / \mathrm{h} \text {. }\end{array}$ & $\begin{array}{l}\text { Two green roofs, } \\
\text { one considering Radix } \\
\text { Ophiopogonis vegetation } \\
\text { and another considering } \\
\text { sedum was used for } \\
\text { performance evaluation. } \\
\text { Overall runoff reduction } \\
\text { over the } 66 \text { rainfall events } \\
\text { was found to be } 21 \% \text { for } \\
\text { Radix Ophiopogonis and } \\
31.3 \% \text { for sedum vegetation. }\end{array}$ & $\begin{array}{l}\text { The structural factors, } \\
\text { the substrate material, and the } \\
\text { depth were seen to be the most } \\
\text { significant criteria for the green } \\
\text { roof stormwater retention. }\end{array}$ & [79] \\
\hline 44 & $\begin{array}{c}\text { Rio de Janeiro, } \\
\text { Brazil } \\
\text { Monitoring }\end{array}$ & 0.5 sq. meter & $\begin{array}{l}\text { Artificial rainfall of } \\
155 \mathrm{~mm} / \mathrm{h} \text { intensity was } \\
\text { simulated for } 7 \text { min } \\
\text { duration, with temperatures } \\
\text { ranging from } 29-34^{\circ} \mathrm{C} \text {. }\end{array}$ & $\begin{array}{l}\text { The experiment was } \\
\text { repeated with wet and dry } \\
\text { soil, where the reduction in } \\
\text { runoff was found to be } \\
31.18-35.43 \% \text { for wet soil, } \\
\text { and } 62.08-85.19 \% \text { for dry } \\
\text { soil. }\end{array}$ & $\begin{array}{l}\text { The use of modular-green roof } \\
\text { systems showed an important } \\
\text { impact on postponing } \\
\text { hydrographs peak-flows but, } \\
\text { jointly with hydrograph } \\
\text { abatement, there is rainwater } \\
\text { retention in the green roof } \\
\text { modular system. This would } \\
\text { contribute to flood control, } \\
\text { especially for densely occupied } \\
\text { urban areas. }\end{array}$ & [110] \\
\hline 45 & $\begin{array}{c}\text { Fisciano, Italy } \\
\text { Monitoring }\end{array}$ & 2.5 sq. meter & $\begin{array}{l}\text { The study considered } \\
35 \text { rainfall events with } \\
\text { cumulative rainfall per } \\
\text { event ranging from } \\
0.5-122.17 \text { mm, and with } \\
\text { duration ranging from } \\
\text { 35-4565 min. }\end{array}$ & $\begin{array}{l}\text { The green roof performance } \\
\text { in runoff reduction ranged } \\
\text { from } 4-100 \% \text {, depending on } \\
\text { the intensity, duration, } \\
\text { and amount of rainfall. }\end{array}$ & $\begin{array}{l}\text { Rainfall events depend on } \\
\text { factors such as long duration, } \\
\text { high cumulate depth, } \\
\text { and rainfall intensity. } \\
\text { A longer monitoring period } \\
\text { would probably increase the } \\
\text { probability of facing rainfall } \\
\text { events with longer return } \\
\text { periods. }\end{array}$ & [113] \\
\hline
\end{tabular}

A total of 62 rainfall events from October 2015-September 2016 were considered, with the total Arcavacata, Italy $46 \quad$ Modeling (HYDRUS-1D) 50 sq. meter rainfall per event ranging from $2.0-120.1 \mathrm{~mm}$, rainfall intensity ranging from $0.4-13.5 \mathrm{~mm} / \mathrm{h}$ and duration ranging from $12 \mathrm{~min}-61 \mathrm{~h} 31 \mathrm{~min}$.
The simulation study indicated that the overall reduction in runoff varies from $22 \%$ for $60 \mathrm{~mm}$ soil depths to $24 \%$ for $150 \mathrm{~mm}$ soil depths.
Peak flow reduction, peak flow lag time, etc., have correlations with the hydrological features of storm events.
A total of 19 individual storm events were considered in the study,

$47 \begin{gathered}\text { Porto Alegre, } \\ \text { Brazil } \\ \text { Monitoring }\end{gathered}$
where total precipitation per event ranged from 11.87-139.54 mm, with duration ranging from $4 \mathrm{~h} 10 \mathrm{~min}$ to $71 \mathrm{~h} 50 \mathrm{~min}$.
The percentage reduction of runoff per storm event was found to be between 42.9-80\%.
The green roof structures showed a reduction in the volume of drained water. The green roof is composed of plants that have the capacity to retain water. The plants control the volume of runoff which is vital for reducing the volume of water sent to drainage systems. This helps in reducing the risk of flooding.

\section{References}

1. Huang, C.L.; Hsu, N.S.; Liu, H.J.; Huang, Y.H. Optimization of low impact development layout designs for megacity flood mitigation. J. Hydrol. 2018, 564, 542-558. [CrossRef]

2. UN. World Urbanization Prospects: The 2014 Revision-Highlights; UN: New York, NY, USA, 2014.

3. Fassman, E.A.; Blackbourn, S. Urban runoff mitigation by a permeable pavement system over impermeable soils. J. Hydrol. Eng. 2010, 15, 475-485. [CrossRef]

4. Grebel, J.E.; Mohanty, S.K.; Torkelson, A.A.; Boehm, A.B.; Higgins, C.P.; Maxwell, R.M.; Nelson, K.L.; Sedlak, D.L. Engineered infiltration systems for urban stormwater reclamation. Environ. Eng. Sci. 2013, 30, 437-454. [CrossRef] 
5. Pauleit, S.; Ennos, R.; Golding, Y. Modeling the environmental impacts of urban land use and land cover change-A study in Merseyside, UK. Landsc. Urban Plan. 2005, 71, 295-310. [CrossRef]

6. Alizadehtazi, B.; DiGiovanni, K.; Foti, R.; Morin, T.; Shetty, N.H.; Montalto, F.A.; Gurian, P.L. Comparison of observed infiltration rates of different permeable urban surfaces using a cornell sprinkle infiltrometer. J. Hydrol. Eng. 2016, 21, 06016003. [CrossRef]

7. Graves, A.R.; Morris, J.; Deeks, L.K.; Rickson, R.J.; Kibblewhite, M.G.; Harris, J.A.; Farewell, T.S.; Truckle, I. The total costs of soil degradation in England and Wales. Ecol. Econ. 2015, 119, 399-413. [CrossRef]

8. Bai, T.; Mayer, A.L.; Shuster, W.D.; Tian, G. The hydrologic role of urban green space in mitigating flooding (Luohe, China). Sustainability 2018, 10, 3584. [CrossRef]

9. Miller, J.D.; Kim, H.; Kjeldsen, T.R.; Packman, J.; Grebby, S.; Dearden, R. Assessing the impact of urbanization on storm runoff in a peri-urban catchment using historical change in impervious cover. J. Hydrol. 2014, 515, 59-70. [CrossRef]

10. Yang, J.L.; Zhang, G.L. Water infiltration in urban soils and its effects on the quantity and quality of runoff. J. Soils Sediments 2011, 11, 751-761. [CrossRef]

11. Liu, C.; Li, Y.; Li, J. Geographic information system-based assessment of mitigating flash-flood disaster from green roof systems. Comput. Environ. Urban Syst. 2017, 64, 321-331. [CrossRef]

12. Du, S.; Shi, P.; Van Rompaey, A.; Wen, J. Quantifying the impact of impervious surface location on flood peak discharge in urban areas. Nat. Hazards 2015, 76, 1457-1471. [CrossRef]

13. Wang, D.; Hejazi, M. Quantifying the relative contribution of the climate and direct human impacts on mean annual streamflow in the contiguous United States. Water Resour. Res. 2011, 47, 1-16. [CrossRef]

14. Zhou, F.; Xu, Y.; Chen, Y.; Xu, C.Y.; Gao, Y.; Du, J. Hydrological response to urbanization at different spatio-temporal scales simulated by coupling of CLUE-S and the SWAT model in the Yangtze River Delta region. J. Hydrol. 2013, 485, 113-125. [CrossRef]

15. Tomer, M.D.; Schilling, K.E. A simple approach to distinguish land-use and climate-change effects on watershed hydrology. J. Hydrol. 2009, 376, 24-33. [CrossRef]

16. Wu, P.; Christidis, N.; Stott, P. Anthropogenic impact on Earth's hydrological cycle. Nat. Clim. Chang. 2013, 3, 807-810. [CrossRef]

17. Wasko, C.; Sharma, A. Global assessment of flood and storm extremes with increased temperatures. Sci. Rep. 2017, 7, 1-8. [CrossRef] [PubMed]

18. McCabe, G.J.; Wolock, D.M. A step increase in streamflow in the conterminous United States. Geophys. Res. Lett. 2002, 29, 38-1-38-4. [CrossRef]

19. Rougé, C.; Cai, X. Crossing-scale hydrological impacts of urbanization and climate variability in the Greater Chicago Area. J. Hydrol. 2014, 517, 13-27. [CrossRef]

20. La Barbera, P.; Lanza, L.; Parodi, U. A stochastic framework for the modeling of failures in urban drainage systems due to microscale effects. In Modelling of Flood Propagation over Initially Dry Areas; ASCE: Reston, VA, USA, 1994; pp. 197-208.

21. Aronica, G.T.; Lanza, L.G. Drainage efficiency in urban areas: A case study. Hydrol. Process. Int. J. 2005, 19, 1105-1119. [CrossRef]

22. Hatt, B.E.; Fletcher, T.D.; Walsh, C.J.; Taylor, S.L. The influence of urban density and drainage infrastructure on the concentrations and loads of pollutants in small streams. Environ. Manag. 2004, 34, 112-124. [CrossRef]

23. Bauduceau, N.; Berry, P.; Cecchi, C.; Elmqvist, T.; Fernandez, M.; Hartig, T.; Krull, W.; Mayerhofer, E.; Sandra, N.; Noring, L.; et al. Towards an EU Research and Innovation Policy Agenda for Nature-Based Solutions \& Re-Naturing Cities: Final Report of the Horizon 2020 Expert Group on 'Nature-Based Solutions and Re-Naturing Cities'; European Union: Brussels, Belgium, 2015.

24. Maes, J.; Jacobs, S. Nature-based solutions for Europe's sustainable development. Conserv. Lett. 2017, 10, 121-124. [CrossRef]

25. Kumar, P.; Debele, S.E.; Sahani, J.; Aragão, L.; Barisani, F.; Basu, B.; Bucchignani, E.; Charizopoulos, N.; Di Sabatino, S.; Domeneghetti, A.; et al. Towards an operationalisation of nature-based solutions for natural hazards. Sci. Total. Environ. 2020, 731, 138855. [CrossRef] [PubMed]

26. Shah, M.A.R.; Renaud, F.G.; Anderson, C.C.; Wild, A.; Domeneghetti, A.; Polderman, A.; Votsis, A.; Pulvirenti, B.; Basu, B.; Thomson, C.; et al. A review of hydro-meteorological hazard, vulnerability, and risk assessment frameworks and indicators in the context of nature-based solutions. J. Disaster Risk Reduct. 2020, 50, 101728. [CrossRef]

27. Ziegler, A.D.; She, L.H.; Tantasarin, C.; Jachowski, N.R.; Wasson, R. Floods, false hope, and the future. Hydrol. Process. 2012, 26, 1748-1750. [CrossRef]

28. Marchi, L.; Borga, M.; Preciso, E.; Gaume, E. Characterisation of selected extreme flash floods in Europe and implications for flood risk management. J. Hydrol. 2010, 394, 118-133. [CrossRef]

29. De Moel, H.D.; Van Alphen, J.; Aerts, J.C.J.H. Flood maps in Europe-Methods, availability and use. Nat. Hazards Earth Syst. Sci. 2009, 9, 289-301. [CrossRef]

30. Bignami, D.F.; Rosso, R.; Sanfilippo, U. Flood Proofing in Urban Areas; Springer: Berlin/Heidelberg, Germany, 2019.

31. Guerreiro, S.B.; Dawson, R.J.; Kilsby, C.; Lewis, E.; Ford, A. Future heat-waves, droughts and floods in 571 European cities. Environ. Res. Lett. 2018, 13, 034009. [CrossRef]

32. Burgess-Gamble, L.; Ngai, R.; Wilkinson, M.; Nisbet, T.; Pontee, N.; Harvey, R.; Kipling, K.; Addy, S.; Rose, S.; Maslen, S.; et al. Working with Natural Processes-Evidence Directory; Report No. SC150005; Environmental Agency: Bristol, UK, 2017.

33. Jegatheesan, V.; Goonetilleke, A.; Van Leeuwen, J.; Kandasamy, J.; Warner, D.; Myers, B.; Bhuiyan, M.; Spence, K.; Parker, G. (Eds.) Urban Stormwater and Flood Management: Enhancing the Liveability of Cities; Springer: Berlin/Heidelberg, Germany, 2019. 
34. Depietri, Y.; McPhearson, T. Integrating the grey, green, and blue in cities: Nature-based solutions for climate change adaptation and risk reduction. In Nature-Based Solutions to Climate Change Adaptation in Urban Areas; Springer: Cham, Switzerland, 2017; pp. 91-109.

35. Cohen-Shacham, E.; Walters, G.; Janzen, C.; Maginnis, S. Nature-Based Solutions to Address Global Societal Challenges; IUCN: Gland, Switzerland, 2016; p. 97.

36. Kabisch, N.; Korn, H.; Stadler, J.; Bonn, A. Nature-based Solutions to Climate Change Adaptation in Urban Areas: Linkages between Science, Policy and Practice; Springer: Cham, Switzerland, 2017.

37. European Commission (EC). Communication from the Commission to the European Parliament, the Council, the European Economic and Social Committee and the Committee of The Regions Next Steps for a Sustainable European Future-European Action for Sustainability; COM/2016/0739; European Union: Brussels, Belgium, 2016.

38. UNDRR. Sendai framework for disaster risk reduction 2015-2030. In Proceedings of the 3rd United Nations World Conference on DRR, Sendai, Japan, 18 March 2015; pp. 14-18.

39. Pecl, G.T.; Araújo, M.B.; Bell, J.D.; Blanchard, J.; Bonebrake, T.C.; Chen, I.C.; Clark, T.D.; Colwell, R.K.; Danielsen, F.; Evengård, B.; et al. Biodiversity redistribution under climate change: Impacts on ecosystems and human well-being. Science 2017, 355, eaai9214. [CrossRef]

40. Dudley, N.; Stolton, S.; Belokurov, A.; Krueger, L.; Lopoukhine, N.; MacKinnon, K.; Sandwith, T.; Sekhran, N. Natural solutions: Protected areas helping people cope with climate change. In Natural Solutions: Protected Areas Helping People Cope with Climate Change; IUCN/WCPA “Parks for Life” Coordination Office: Ljubljana, Slovenia, 2010.

41. Arkema, K.K.; Griffin, R.; Maldonado, S.; Silver, J.; Suckale, J.; Guerry, A.D. Linking social, ecological, and physical science to advance natural and nature-based protection for coastal communities. Ann. N. Y. Acad. Sci. 2017, 1399, 5-26. [CrossRef]

42. Wild, T.C.; Henneberry, J.; Gill, L. Comprehending the multiple 'values' of green infrastructure-Valuing nature-based solutions for urban water management from multiple perspectives. Environ. Res. 2017, 158, 179-187. [CrossRef]

43. Lafortezza, R.; Chen, J.; Van Den Bosch, C.K.; Randrup, T.B. Nature-based solutions for resilient landscapes and cities. Environ. Res. 2018, 165, 431-441. [CrossRef]

44. Sallustio, L.; Perone, A.; Vizzarri, M.; Corona, P.; Fares, S.; Cocozza, C.; Tognetti, R.; Lasserre, B.; Marchetti, M. The green side of the grey: Assessing greenspaces in built-up areas of Italy. Urban For. Urban Green. 2019, 37, 147-153. [CrossRef]

45. Thorslund, J.; Jarsjo, J.; Jaramillo, F.; Jawitz, J.W.; Manzoni, S.; Basu, N.B.; Chalov, S.R.; Cohen, M.J.; Creed, I.F.; Goldenberg, R.; et al. Wetlands as large-scale nature-based solutions: Status and challenges for research, engineering and management. Ecol. Eng. 2017, 108, 489-497. [CrossRef]

46. Frantzeskaki, N.; Borgström, S.; Gorissen, L.; Egermann, M.; Ehnert, F. Nature-based solutions accelerating urban sustainability transitions in cities: Lessons from Dresden, Genk and Stockholm cities. In Nature-Based Solutions to Climate Change Adaptation in Urban Areas; Springer: Cham, Switzerland, 2017; pp. 65-88.

47. Zölch, T.; Henze, L.; Keilholz, P.; Pauleit, S. Regulating urban surface runoff through nature-based solutions-An assessment at the micro-scale. Environ. Res. 2017, 157, 135-144. [CrossRef]

48. Kabisch, N.; Strohbach, M.; Haase, D.; Kronenberg, J. Urban green space availability in European cities. Ecol. Indic. 2016, 70, 586-596. [CrossRef]

49. Raymond, C.M.; Breil, M.; Nita, M.R.; Kabisch, N.; de Bel, M.; Enzi, V.; Frantzeskaki, N.; Geneletti, G.; Lovinger, L.; Cardinaletti, M.; et al. An Impact Evaluation Framework to Support Planning and Evaluation of Nature-Based Solutions Projects. Report Prepared by the EKLIPSE Expert Working Group on Nature-Based Solutions to Promote Climate Resilience in Urban Areas; Centre for Ecology and Hydrology: Wallingford, UK, 2017.

50. Faivre, N.; Fritz, M.; Freitas, T.; de Boissezon, B.; Vandewoestijne, S. Nature-Based Solutions in the EU: Innovating with nature to address social, economic and environmental challenges. Environ. Res. 2017, 159, 509-518. [CrossRef] [PubMed]

51. Debele, S.E.; Kumar, P.; Sahani, J.; Marti-Cardona, B.; Mickovski, S.B.; Leo, L.S.; Porcù, F.; Bertini, F.; Montesi, D.; Vojinovic, Z.; et al. Nature-based solutions for hydro-meteorological hazards: Revised concepts, classification schemes and databases. Environ. Res. 2019, 178, 108799. [CrossRef]

52. Sahani, J.; Kumar, P.; Debele, S.; Spyrou, C.; Loupis, M.; Aragão, L.; Porcù, F.; Shah, M.A.R.; Di Sabatino, S. Hydro-meteorological risk assessment methods and management by nature-based solutions. Sci. Total. Environ. 2019, 696, 133936. [CrossRef]

53. Santo, M.A.; Gallotti, G.; Basu, B.; Armigliato, A.; Spyrou, C.; Salmivaara, A.; Ruggieri, P.; Pilla, F.; Basu, A.S.; Apostolidou, E.A.; et al. A modelling approach to assess Nature Based Solutions efficiency. In Proceedings of the AGU Fall Meeting 2020 , San Francisco, CA, USA, 7-11 December 2020; AGU: Washington, DC, USA, 2020.

54. Wong, T.H. Water sensitive urban design-the journey thus far. Australas. J. Water Res. 2006, 10, 213-222. [CrossRef]

55. Haase, D. Urban wetlands and Riparian forests as a nature-based solution for climate change adaptation in cities and their surroundings. In Nature-Based Solutions to Climate Change Adaptation in Urban Areas; Springer: Cham, Switzerland, 2017; pp. 111-121.

56. Ritchie, A.; Thomas, R. (Eds.) Sustainable Urban Design: An Environmental Approach; Taylor \& Francis: Abingdon, UK, 2013.

57. Snodgrass, E.C.; McIntyre, L. The Green Roof Manual: A Professional Guide to Design, Installation, and Maintenance; Timber Press: Portland, OR, USA, 2010.

58. Moher, D.; Liberati, A.; Tetzlaff, J.; Altman, D.G. Preferred reporting items for systematic reviews and meta-analyses: The PRISMA statement. Ann. Intern. Med. 2009, 151, 264-269. [CrossRef] 
59. Shamseer, L.; Moher, D.; Clarke, M.; Ghersi, D.; Liberati, A.; Petticrew, M.; Whitlock, E. Preferred reporting items for systematic review and meta-analysis protocols (prisma-p) 2015: Elaboration and explanation. BMJ 2015, 349, 1-25. [CrossRef]

60. Berndtsson, J.C. Green roof performance towards management of runoff water quantity and quality: A review. Ecol. Eng. 2010, 36, 351-360. [CrossRef]

61. Köhler, M.; Schmidt, M.; Laar, M. Green roofs as a contribution to reduce urban heat islands. In Proceedings of the World Climate and Energy Event, Rio de Janeiro, Brazil, 1-5 December 2003; pp. 1-5.

62. Herman, R. Green roofs in Germany: Yesterday, today and tomorrow. In Proceedings of the Conference: The First North American Green Roof Infrastructure Conference, Awards and Trade Show: Greening Rooftops for Sustainable Communities, Chicago, IL, USA, 29-30 May 2003; pp. 41-45.

63. Forschungsgesellschaft Landschaftsentwicklung Landschaftsbau. Guideline for the Planning, Execution and Upkeep of Green-Roof Sites; Forschungsgesellschaft Landschaftsentwicklung Landschaftsbau: Bonn, Germany, 2002.

64. Brenneisen, S. Space for urban wildlife: Designing green roofs as habitats in Switzerland. Urban Habitats 2006, 4, 27-36.

65. Newton, J. Building Greener: Guidance on the Use of Green Roofs, Green Walls and Complementary Features on Buildings; Ciria: London, UK, 2007.

66. Ngan, G. Green Roof Policies; Landscape Architecture Canada Foundation: Ottawa, ON, Canada, 2004.

67. European Commission (EC) Directive. Commission Staff Working Document, Guidance on a Strategic Framework for Further Supporting the Deployment of EU Level Green and Blue Infrastructure; SWD/2019/193; European Union: Brussels, Belgium, 2019.

68. European Commission (EC) Directive. Energy Performance of buildings (recast). Off. J. Eur. Union 2010, 153, 13-35.

69. Drainage Drenage. Greater Dublin Strategic Drainage Study Final Strategy Report; Dublin Drainage: Dublin, Ireland, 2005.

70. Torney, D. Public Consultation on Dublin City Council Draft Climate Change Action Plan; Dublin City University: Dublin, Ireland, 2019.

71. Carson, T.B.; Marasco, D.E.; Culligan, P.J.; McGillis, W.R. Hydrological performance of extensive green roofs in New York City: Observations and multi-year modeling of three full-scale systems. Environ. Res. Lett. 2013, 8, 024036. [CrossRef]

72. Carbone, M.; Garofalo, G.; Nigro, G.; Piro, P. Green roofs in the Mediterranean area: Interaction between native plant species and sub-surface runoff. In Applied Mechanics and Materials; Trans Tech Publications Ltd: Bach, Switzerland, 2015; Volume 737, pp. 749-753.

73. Yang, W.Y.; Li, D.; Sun, T.; Ni, G.H. Saturation-excess and infiltration-excess runoff on green roofs. Ecol. Eng. 2015, 74, 327-336. [CrossRef]

74. Soulis, K.X.; Ntoulas, N.; Nektarios, P.A.; Kargas, G. Runoff reduction from extensive green roofs having different substrate depth and plant cover. Ecol. Eng. 2017, 102, 80-89. [CrossRef]

75. Speak, A.F.; Rothwell, J.J.; Lindley, S.J.; Smith, C.L. Rainwater runoff retention on an aged intensive green roof. Sci. Total. Environ. 2013, 461, 28-38. [CrossRef] [PubMed]

76. Mentens, J.; Raes, D.; Hermy, M. Green roofs as a tool for solving the rainwater runoff problem in the urbanized 21st century? Landsc. Urban Plan. 2006, 77, 217-226. [CrossRef]

77. Stovin, V.; Vesuviano, G.; Kasmin, H. The hydrological performance of a green roof test bed under UK climatic conditions. J. Hydrol. 2012, 414, 148-161. [CrossRef]

78. Dunnett, N.; Kingsbury, N. Planting Green Roofs and Living Walls; Timber Press: Portland, OR, USA, 2008.

79. Liu, W.; Feng, Q.; Chen, W.; Wei, W.; Deo, R.C. The influence of structural factors on stormwater runoff retention of extensive green roofs: New evidence from scale-based models and real experiments. J. Hydrol. 2019, 569, 230-238. [CrossRef]

80. Schroll, E.; Lambrinos, J.; Righetti, T.; Sandrock, D. The role of vegetation in regulating stormwater runoff from green roofs in a winter rainfall climate. Ecol. Eng. 2011, 37, 595-600. [CrossRef]

81. Jim, C.Y.; Tsang, S.W. Ecological energetics of tropical intensive green roof. Energy Build. 2011, 43, 2696-2704. [CrossRef]

82. Bengtsson, L.; Grahn, L.; Olsson, J. Hydrological function of a thin extensive green roof in southern Sweden. Hydrol. Res. 2005, 36, 259-268. [CrossRef]

83. Carter, T.; Jackson, C.R. Vegetated roofs for stormwater management at multiple spatial scales. Landsc. Urban Plan. 2007, 80, 84-94. [CrossRef]

84. Hilten, R.N.; Lawrence, T.M.; Tollner, E.W. Modeling stormwater runoff from green roofs with HYDRUS-1D. J. Hydrol. 2008, 358, 288-293. [CrossRef]

85. Berghage, R.D.; Beattie, D.; Jarrett, A.R.; Thuring, C.; Razaei, F.; O'Connor, T.P. Green Roofs for Stormwater Runoff Control. 2009. Available online: https:/ / cfpub.epa.gov/si/si_public_record_report.cfm?dirEntryId=205444\&Lab=NRMRL (accessed on 24 November 2021).

86. Feitosa, R.C.; Wilkinson, S. Modelling green roof stormwater response for different soil depths. Landsc. Urban Plan. 2016, 153, 170-179. [CrossRef]

87. Carpenter, D.D.; Kaluvakolanu, P. Effect of roof surface type on storm-water runoff from full-scale roofs in a temperate climate. J. Irrig. Drain. Eng. 2011, 137, 161-169. [CrossRef]

88. Carter, T.L.; Rasmussen, T.C. Hydrologic behavior of vegetated roofs 1. JAWRA Assoc. 2006, 42, 1261-1274. [CrossRef]

89. Li, Y.; Babcock, R.W., Jr. Green roof hydrologic performance and modeling: A review. Water Sci. Technol. 2014, 69, 727-738. [CrossRef] 
90. Dunnett, N. Green roofs for biodiversity: Reconciling aesthetics with ecology. In Proceedings of the 4th Annual Greening Rooftops for Sustainable Communities, Boston, MA, USA, 11-12 May 2006; pp. 11-12.

91. Williams, N.S.; Lundholm, J.; Scott MacIvor, J. Do green roofs help urban biodiversity conservation? J. Appl. Ecol. 2014, 51, 1643-1649. [CrossRef]

92. Zinzi, M.; Agnoli, S. Cool and green roofs. An energy and comfort comparison between passive cooling and mitigation urban heat island techniques for residential buildings in the Mediterranean region. Energy Build. 2012, 55, 66-76. [CrossRef]

93. Alexandri, E.; Jones, P. Temperature decreases in an urban canyon due to green walls and green roofs in diverse climates. Build. Environ. 2008, 43, 480-493. [CrossRef]

94. Jaffal, I.; Ouldboukhitine, S.E.; Belarbi, R. A comprehensive study of the impact of green roofs on building energy performance. Renew. Energy 2012, 43, 157-164. [CrossRef]

95. Lee, K.E.; Williams, K.J.; Sargent, L.D.; Williams, N.S.; Johnson, K.A. 40-second green roof views sustain attention: The role of micro-breaks in attention restoration. J. Environ. Psychol. 2015, 42, 182-189. [CrossRef]

96. White, E.V.; Gatersleben, B. Greenery on residential buildings: Does it affect preferences and perceptions of beauty? J. Environ Psychol. 2011, 31, 89-98. [CrossRef]

97. Yang, J.; Yu, Q.; Gong, P. Quantifying air pollution removal by green roofs in Chicago. Atmos. Environ. 2008, 42, 7266-7273. [CrossRef]

98. Currie, B.A.; Bass, B. Estimates of air pollution mitigation with green plants and green roofs using the UFORE model. Urban Ecosyst. 2008, 11, 409-422. [CrossRef]

99. Rowe, D.B. Green roofs as a means of pollution abatement. Environ. Pollut. 2011, 159, 2100-2110. [CrossRef]

100. Graceson, A.; Hare, M.; Monaghan, J.; Hall, N. The water retention capabilities of growing media for green roofs. Ecol. Eng. 2013, 61, 328-334. [CrossRef]

101. Kemp, S.; Hadley, P.; Blanuša, T. The influence of plant type on green roof rainfall retention. Urban Ecosyst. 2019, 22, 355-366. [CrossRef]

102. Baudoin, W.; Desjardins, Y.; Dorais, M.; Charrondière, U.R.; Herzigova, L.; El-Behairy, U.; Metwaly, N.; Marulanda, C.; Ba, N. Rooftop Gardening for Improved Food and Nutrition Security in the Urban Environment. In Rooftop Urban Agriculture; Springer: Cham, Switzerland, 2017; pp. 219-233.

103. Jungels, J.; Rakow, D.A.; Allred, S.B.; Skelly, S.M. Attitudes and aesthetic reactions toward green roofs in the Northeastern United States. Landsc. Urban Plan. 2013, 117, 13-21. [CrossRef]

104. Whittinghill, L.J.; Rowe, D.B.; Cregg, B.M. Evaluation of vegetable production on extensive green roofs. Agroecol. Sustain. Food Syst. 2013, 37, 465-484. [CrossRef]

105. Organisation, G.R. The Gro Green Roof Code: Green Roof Code of Best Practice for the UK 2011; Groundwork: Sheffield, UK, 2011.

106. Kosareo, L.; Ries, R. Comparative environmental life cycle assessment of green roofs. Build. Environ. 2007, 42, 2606-2613. [CrossRef]

107. Razzaghmanesh, M.; Beecham, S. The hydrological behaviour of extensive and intensive green roofs in a dry climate. Sci. Total. Environ. 2014, 499, 284-296. [CrossRef]

108. Lee, J.Y.; Lee, M.J.; Han, M. A pilot study to evaluate runoff quantity from green roofs. J. Environ. Manag. 2015, 152, 171-176. [CrossRef]

109. Schultz, I.; Sailor, D.J.; Starry, O. Effects of substrate depth and precipitation characteristics on stormwater retention by two green roofs in Portland OR. J. Hydrol. 2018, 18, 110-118. [CrossRef]

110. Loiola, C.; Mary, W.; da Silva, L.P. Hydrological performance of modular-tray green roof systems for increasing the resilience of mega-cities to climate change. J. Hydrol. 2019, 573, 1057-1066. [CrossRef]

111. Stovin, V. The potential of green roofs to manage urban stormwater. Water Environ. J. 2010, 24, 192-199. [CrossRef]

112. Brandão, C.; do Rosário Cameira, M.; Valente, F.; de Carvalho, R.C.; Paço, T.A. Wet season hydrological performance of green roofs using native species under Mediterranean climate. Ecol. Eng. 2017, 102, 596-611. [CrossRef]

113. Longobardi, A.; D’Ambrosio, R.; Mobilia, M. Predicting Stormwater Retention Capacity of Green Roofs: An Experimental Study of the Roles of Climate, Substrate Soil Moisture, and Drainage Layer Properties. Sustainability 2019, 11, 6956. [CrossRef]

114. Burszta-Adamiak, E.; Mrowiec, M. Modelling of green roofs' hydrologic performance using EPA's SWMM. Water Sci. Technol. 2013, 68, 36-42. [CrossRef] [PubMed]

115. Oviedo, N.; Torres, A. Hydrologie Attenuation and the Hydrologie Benefits of Implementing Eco-Productive Green Roofs in Marginal Urban Areas. Ing. Univ. 2014, 18, 291-308.

116. Shin, E.; Kim, H. Analysing Green Roof Effects in an Urban Environment: A Case of Bangbae-dong, Seoul. J. Asian Archit. Building Eng. 2015, 14, 315-322. [CrossRef]

117. Masseroni, D.; Cislaghi, A. Green roof benefits for reducing flood risk at the catchment scale. Environ. Earth Sci. 2016, 75, 579. [CrossRef]

118. Giacomoni, M.H.; Joseph, J. Multi-objective evolutionary optimization and Monte Carlo simulation for placement of low impact development in the catchment scale. J. Water Res. Plan. Manag. 2017, 143, 04017053. [CrossRef]

119. Stovin, V.; Poë, S.; Berretta, C. A modelling study of long term green roof retention performance. J. Environ. Manag. 2013, 131, 206-215. [CrossRef] 
120. Hakimdavar, R.; Culligan, P.J.; Finazzi, M.; Barontini, S.; Ranzi, R. Scale dynamics of extensive green roofs: Quantifying the effect of drainage area and rainfall characteristics on observed and modeled green roof hydrologic performance. Ecol. Eng. 2014, 73, 494-508. [CrossRef]

121. Palermo, S.A.; Turco, M.; Principato, F.; Piro, P. Hydrological effectiveness of an extensive green roof in Mediterranean climate. Water 2019, 11, 1378. [CrossRef]

122. Liu, C.; Li, Y. Measuring eco-roof mitigation on flash floods via GIS simulation. Built Environ. Proj. Asset. Manag. 2016, 6, 415-427. [CrossRef]

123. Roehr, D.; Kong, Y. Runoff reduction effects of green roofs in Vancouver, BC, Kelowna, BC, and Shanghai, PR China. Can. Water Resour. J. 2010, 35, 53-68. [CrossRef]

124. Schmitter, P.; Goedbloed, A.; Galelli, S.; Babovic, V. Effect of catchment-scale green roof deployment on stormwater generation and reuse in a tropical city. J. Water Res. Plan. Manag. 2016, 142, 05016002. [CrossRef]

125. Gao, J.; Wang, R.; Huang, J.; Liu, M. Application of BMP to urban runoff control using SUSTAIN model: Case study in an industrial area. Ecol. Model. 2015, 318, 177-183. [CrossRef]

126. Metselaar, K. Water retention and evapotranspiration of green roofs and possible natural vegetation types. Resour. Conserv. Recycl. 2012, 64, 49-55. [CrossRef]

127. Palla, A.; Sansalone, J.J.; Gnecco, I.; Lanza, L.G. Storm water infiltration in a monitored green roof for hydrologic restoration. Water Sci. Technol. 2011, 64, 766-773. [CrossRef]

128. Allen, R.G.; Pereira, L.S.; Raes, D.; Smith, M. Crop evapotranspiration-Guidelines for computing crop water requirements-FAO Irrigation and drainage paper 56. FAO: Rome, Italy, 1998.

129. Pilla, F.; Gharbia, S.S.; Lyons, R. How do households perceive flood-risk? The impact of flooding on the cost of accommodation in Dublin, Ireland. Sci. Total. Environ. 2019, 650, 144-154. [CrossRef] [PubMed]

130. Basu, B.; Sarkar, A.; Pilla, F. Identification of optimal number of rain gauges and their locations based on different statistical approaches: A case study in Dublin based on hourly and daily rainfall data. Geophys. Res. Abstr. 2019, 21, 1.

131. Sarkar Basu, A.; Basu, B.; Sannigrahi, S.; Pilla, F. Deployment of Green roof top as a Nature Based Solution in Dublin, Ireland. In Proceedings of the 22nd EGU General Assembly, Vienna, Austria, 4-8 May 2020; p. 12215.

132. Éireann, M. Climate of Ireland. Met Eireann. 2009. Available online: https:/ /www.met.ie/ (accessed on 21 November 2021).

133. Brouwer, C.; Goffeau, A.; Heibloem, M. Irrigation Water Management: Training Manual No. 1-Introduction to Irrigation; Food and Agriculture Organization of the United Nations: Rome, Italy, 1985; pp. 102-103.

134. Te Chow, V. Applied Hydrology; Tata McGraw-Hill Education: New York, NY, USA, 2010.

135. Pineda-Martos, R.; Calheiros, C.S. Nature-Based Solutions in Cities-Contribution of the Portuguese National Association of Green Roofs to Urban Circularity. Circ. Econ. Sustain. 2021, 1, 1-17. [CrossRef]

136. Calheiros, C.S.C.; Castiglione, B.; Palha, P. Nature-based solutions for socially and environmentally responsible new cities: The contribution of green roofs. In Circular Economy and Sustainability; Elsevier: Amsterdam, The Netherlands, $2022 ;$ pp. $235-255$.

137. Getter, K.L.; Rowe, D.B.; Andresen, J.A. Quantifying the effect of slope on extensive green roof stormwater retention. Ecol. Eng. 2007, 31, 225-231. [CrossRef]

138. Van Seters, T.; Rocha, L.; Smith, D.; MacMillan, G. Evaluation of green roofs for runoff retention, runoff quality, and leachability. Water Qual. Res. J. 2009, 44, 33-47. [CrossRef]

139. Fioretti, R.; Palla, A.; Lanza, L.G.; Principi, P. Green roof energy and water related performance in the Mediterranean climate. Build. Environ. 2010, 45, 1890-1904. [CrossRef]

140. Morgan, S.; Celik, S.; Retzlaff, W. Green roof storm-water runoff quantity and quality. J. Environ. Eng. 2013, 139, 471-478. [CrossRef]

141. Fassman-Beck, E.; Voyde, E.; Simcock, R.; Hong, Y.S. 4 Living roofs in 3 locations: Does configuration affect runoff mitigation? J. Hydrol. 2013, 490, 11-20. [CrossRef]

142. Wong, G.K.; Jim, C.Y. Quantitative hydrologic performance of extensive green roof under humid-tropical rainfall regime. Ecol. Eng. 2014, 70, 366-378. [CrossRef]

143. Nawaz, R.; McDonald, A.; Postoyko, S. Hydrological performance of a full-scale extensive green roof located in a temperate climate. Ecol. Eng. 2015, 82, 66-80. [CrossRef]

144. Sobczyk, M.; Mrowiec, M. Retention capacity of extensive green roofs. J. Water Land Dev. 2016, 30, 113-117. [CrossRef]

145. Shafique, M.; Lee, D.; Kim, R. A field study to evaluate runoff quantity from blue roof and green blue roof in an urban area. Int. J. Control. Autom. 2016, 9, 59-68. [CrossRef]

146. Li, X.; Cao, J.; Xu, P.; Fei, L.; Dong, Q.; Wang, Z. Green roofs: Effects of plant species used on runoff. Land Degrad. Dev. 2018, 29, 3628-3638. [CrossRef]

147. Shafique, M.; Kim, R.; Kyung-Ho, K. Green roof for stormwater management in a highly urbanized area: The case of Seoul, Korea. Sustainability 2018, 10, 584. [CrossRef]

148. Castro, A.S.; Goldenfum, J.A.; da Silveira, A.L.; DallAgnol, A.L.B.; Loebens, L.; Demarco, C.F.; Leandro, D.; Nadaleti, W.C.; Quadro, M.S. The analysis of green roof's runoff volumes and its water quality in an experimental study in Porto Alegre, Southern Brazil. Environ. Sci. Pollut. Res. 2020, 27, 1-15. [CrossRef] 